Article

\title{
The German Wine Market: A Comprehensive Strategic and Economic Analysis
}

\author{
Marc Dressler
}

Management and Entrepreneurship, University of Ludwigshafen, Ernst-Boehe-Str. 4, D-67059 Ludwigshafen, Germany; marc.dressler@hs-lu.de

Received: 25 July 2018; Accepted: 15 November 2018; Published: 21 November 2018

check for updates

\begin{abstract}
Even though it is famous for beer, Germany offers one of the most attractive wine markets, exemplified by being the fourth biggest wine consumption market and a world champion in sparkling wine consumption as well as in wine imports. Still, fragmentation, intensive competition, lack of growth, and a changing environment speak to a challenging market for suppliers. In the absence of a comprehensive investigation on the market, this article aspires to deliver an economic and strategic market analysis. The statistical data is therefore complemented by the primary market research, notably online surveys on strategy and innovation, a proprietary database on wineries' reputation, and an international expert survey on export success factors. The following market study aims to provide a concise overview covering the relevant market data, and to disclose strategic information about the German wine industry beyond pure market statistics. The German wine market, in the stable wine volume sold, shows dynamism underneath "the tip of the iceberg", with industry specific environmental forces. Indeed, as the wine industry deals with agricultural products of a high emotional utility, players need to address the world of commodities and of differentiation. Structural changes are visible in the drive-out of players. Moreover, diverse and even restricting environmental factors motivate supplier's innovation. The key is the changing consumer. Adaptive and innovative suppliers seize market opportunities and expand, despite a lack of market growth. Although the overall price level of wine in the German market is comparatively low, a voluminous premium market exists, where consumers search for experience. Sustainability has been gaining ground, and in cases of appealing offerings and strategic profiling, wineries outperform intensive rivalries and are not limited by missing growth perspectives. Expenditures for marketing will further increase, and cost management is indispensable. Success in the German wine business requires an in-depth knowledge of the complex market and its evolution.
\end{abstract}

Keywords: German wine industry; economic analysis; industry value analysis; strategic market analysis; supplier landscape; strategic grouping

\section{Introduction}

Germany is internationally well-known for its industrial goods and less known for its agricultural or emotional products, such as wine, although it possesses a longstanding wine culture. Although being famous for beer consumption, the German wine market is the fourth largest in the world [1]. As wine has become a global business, with more than $40 \%$ of the goods crossing national barriers [2], in-depth insight into this market allows for the preparation of market entry or to sharpen ones strategy when already participating in the market. Accessible data is fragmented and stems from different providers, sometimes delivering inconsistent information. Fulfilling economic and managerial requests, a solid market investigation necessitates an assessment of the environment, trends, and dynamics [3,4]. Indeed, an economic view needs to analyze the demand and supply side of the market [5]. The ambitioned holistic analysis integrates the historic and actual data, 
and combines it with forecasts. Because of the lack of such an in-depth analysis of the German wine market, this article delivers a holistic market overview exploiting literature, secondary statistical data, and primary empirical data (e.g., online-panel on strategy and innovation, winery performance databases, consumer research, and export performance interviews). The complete market view aims to cover different institutional perspectives, leaning on the paradigm of strategic management [6-9]. The analyses capture the market structure with detailed insights on supply and demand, covering environmental influences, trends, and changes [10]. Such a strategic market view can serve strategic management decisions concerning the German wine market deriving sustainable strategies, and its implementation with adequate organizational alignment so as to best prepare companies for the future [11-14]. Moreover, the wine industry experiences a disproportionally high economic, cultural, and academic interest [15].

In the following sections, materials and methods explains the approach of the study, with reference to the conventional industry analysis. It lays out the exploitation of the statistical and secondary data, as well as diverse primary research surveys to complement the secondary sources. The subsequent investigation of the German wine industry starts out with a brief historic introduction, and an introductive illustration of the economic value-creation beyond the prime industry agricultural production. A subsequent description of the supply side covers the institutional and product perspectives, and initiates the extensive industry analysis. It includes the strategic landscape, as well as the innovation management of the German wine producers, not neglecting the German wine supply in a global wine market context. Then, an exploration of the wine demand explains the consumption, marketing channels, buying behaviour, and trends in the market, and sheds light on the specificities of the sparkling wine market segment. A chapter on German wine ex- and im-ports rounds up the strategic market view. The disclosing discussion of the market view serves to highlight the results of the strategic analysis, implications for practitioners, limitations, and potential for research.

\section{Materials and Methods}

The ambition of this paper is to provide a full-fledged analysis of the German wine industry. Therefore, exploring the importance of the German wine industry beyond agricultural production, from an economic value-creation perspective was central, as well as gathering the existing dispersed data. The industry analysis [13,16-23] was based on well-established and canonical approaches, plus frameworks (e.g., application of PEST or PESTEL [24-30]), for the strategic evaluation of an industry. Significant changes in the supplier landscape with the blurring of business model boundaries support the enrichment the organizational typology by strategic profiling so as to seize the market structure. The strategic market study also merges secondary and cumulative primary research to overcome obvious differences or inconsistencies (Figure 1). With regards to primary research, the authors exploited the panel data of surveys on strategy and innovation, on key success factors of wine export and the performance perception of Germany, and a proprietary database on wine estates' reputation and performance.

The panel on strategy and innovation with German wineries started in the year 2012, and provides insights to complement the market data with regards to the suppliers' environmental perception, strategic grouping, and innovation management. More than 2500 wineries were invited to participate in the scientific online surveys [31] over a two-year cycle, which also allowed for identifying trends. The resulting database consisted of more than 1100 structured interviews with wineries. In 2018, an additional survey validated the prior findings on environmental perception. For the analysis on wine export, the results of a separate online-questionnaire to global wine experts provided valuable insights. The addressed international wine experts assessed wine export success factors in the context of the wine industry, as well as their perceived performance of German producers. The study was based on an established success factor framework with four success factors [32]. The experts assessed the relevance of the levers for the wine industry and the performance of German producers. A proprietary database on reputation and performance served for further analysis. In order to enable the analysis 
of the reputational effects, the jury grades as quality proxies of three renowned German wine guides were gathered. The database contains more than 1200 wineries with ratings for seven consecutive years (since 2009) on quality and prices.
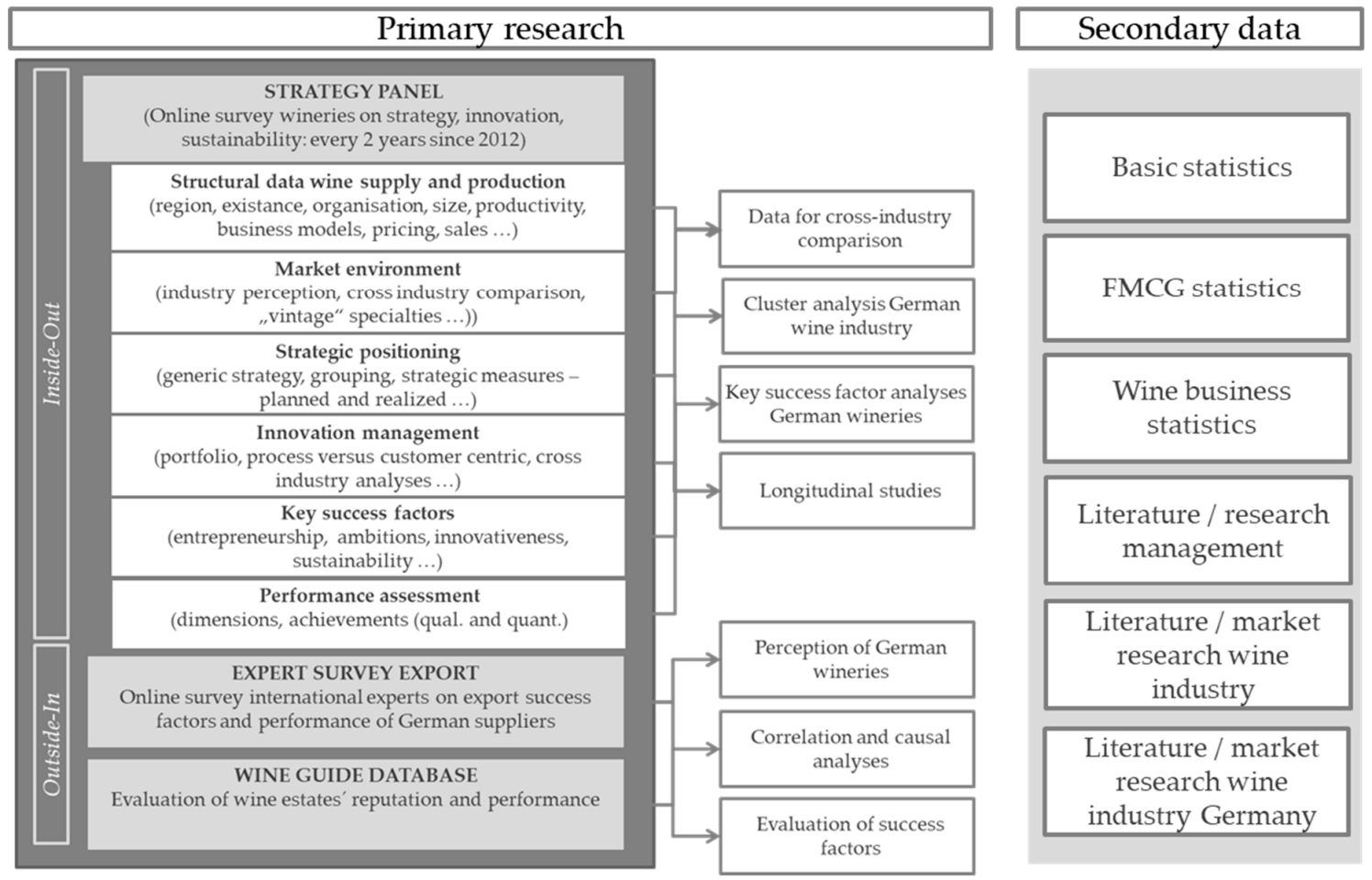

Figure 1. Approach and sources.

\section{Economic and Strategic Market Analysis: The German Wine Market}

\subsection{Wine History and Relevance}

The cultural roots for wine production and consumption in Germany go back to the Roman Empire [33,34]. However, Germanic barbarians also appreciated wine and nurtured a wine culture, as illustrated by their law code, which punished any destruction of vineyards [35]. Religion and Christian customs cultivated wine in Germany. Often cited, Charlemagne was an initiator of an expansion of viticulture in Germany [36,37]. Indeed, the medieval era was a prime time for wine in Germany [38]. The consumption of wine was promoted to consumers instead of unpurified water causing diseases. In particular, the expertise of the Cistercians and other Christian orders improved the production and German wine culture [39]. The still common quality labelled "Kabinett" originated from the monks' storage "cabinet". Over the course of decades, natural and human disasters affected wine production. Phylloxera, peronospora, and oidium, as well as the wars or the economic crises at the beginning of the 20th century, reduced wine production heavily [33,40].

Nowadays, more than half of the surface of Germany serves agriculture [41]. The German agricultural food production on 16.7 million hectares exceeds 50 billion Euros annually [42,43]. Although, making up for more than one tenth of the EU-agricultural production, the direct contribution of agriculture to the German gross national product (GNP) has contracted beyond 1\% [43-45]. Wine plantations account for less than $1 \%$ of the agricultural land [43]. Despite the primary industrial sector's contribution in gross national product diminishing continuously in importance [45], and a modest relevance of wine in German agriculture, wine outreaches a purely agricultural scope. Indeed, the statistics report that more than $6 \%$ of the German agricultural farms produce wine [43]. Accounting for the indirect and network effects, about $7 \%$ of the German GNP is as a result of wine production $[43,46]$. Additionally, the wine industry plays a pivotal role in tourism and gastronomy, 
exceeding the calculated economic contribution [47-51]. Wine has become a characteristic part of Germany and German culture [50,52]. Indeed, famous wines and estates, and a strong regional pride and assertiveness leave a footprint in the wine world. Wine and its positive impact on the landscape lay the foundation for growing travel and tourism [53].

\subsection{The German Wine Supply Side}

\subsubsection{German Wine Production}

On a grapevine area of 102,592 hectares, Germany yields between 8 and 11 million hectoliters of wine annually [54-56]. Thus, Germany ranks at the end of the twenty leading grapevine countries by vineyard area, but it is number ten for volume produced, which speaks to its high productivity $[1,2,57]$. In the 1980s, more than 15 million hectoliters of wine were produced, which reflects the German wine planting and production that were restricted by German and European regulations in regards to surface and yield $[58,59]$. Vineyards can only be planted in designated areas, and new plants have to substitute existing vines if exceeding a growth rate of $0.3 \%$ per year $[33,60,61]$. The yearly output varies as wine is a natural product where temperature, precipitation, and natural hazards (e.g., hail or frost) impact crop yield, but it is also impacted by the quality measures of the vintners [62-68].

Wine grows in thirteen wine growing areas, mainly south of fifty degrees latitude. These regions vary not only in the extend of wine production, but also in the wines, wine styles, production methods, and organization. Rheinhessen is the largest German wine region, making up more than one fourth of the overall wine plantation, followed by the wine region of Palatinate (Figure 2). Jointly, the two regions cover $50 \%$ of the German production area and both belong to the state of Rhineland-Palatinate. The small regions jointly cultivate on less than $10 \%$ of the vineyards.

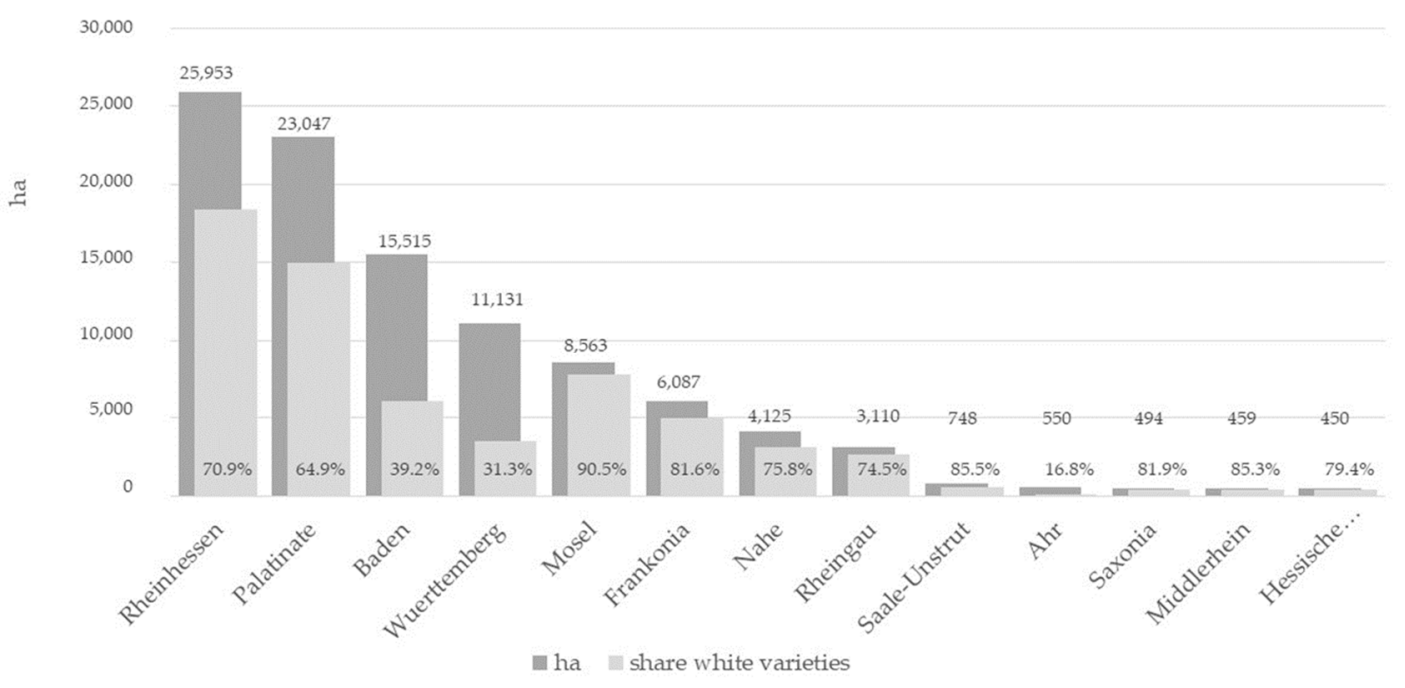

Figure 2. Wine regions by planted surface, and the white wine proportion thereof (2017) [55].

German wine production is predominantly white wine. White wine planting peaked in 1980, with $89 \%$ of the vineyards planted with white varietals, which nowadays covers two thirds of vinelands [69]. The split of white versus red wines varies by region (Figure 2), with Ahr dominated by red wine, whereas Mosel and Rheingau on the other hand are white wine regions. Regarding varietals, Riesling and Müller-Thurgau dominate the white grapevines' portfolio, making up more than half of the white wine vineyards. For the red wines, Pinot Noir, Dornfelder, and Portugieser are prominent [55]. The planted varietals have changed, although vines are a long-lasting crop, and replacing varietals requires investment, with new plants not yielding for at least three years. In 1970, Silvaner was planted on more than one fourth of the German surface. In 1964, Pinot Noir was only at 3\%, and Dornfelder jumped from a mere $0.6 \%$ in 1985 [40]. Nowadays, in the German 
vineyards, Silvaner makes up for 5\%, Pinot Noir 12\%, and Dornfelder 8\% [69]. Indeed, Germany is the leading global Riesling producer, possessing nearly half of the Riesling vineyards, and is third in Pinot Noir planting [55]. Within the European Union, Germany has the youngest vineyards [70]. However, German cultivation exceeds 140 different grapevine varietals [71].

The German wine supply side adapts to the changes in the customer preferences [72]. The trend for biological, organic, and sustainable products is visible in planting. Vineyards with a biological cultivation reached $8 \%$ of the German vineyards [73]. Still, there is a gap to close in order to meet the political target of $20 \%$ ecological agricultural production [74].

In wine, the landscape influences the products, yields, and production [75]. The term "terroir" expresses the complex relationship of soil, temperature, micro-climate, sun, and other factors, all of which have an influence on the grape [76,77]. However, terroir also affects the production and especially the cost of production. The steepness of the vineyards renders nursing more demanding and results in higher production costs [58]. The wine regions of Rhineland-Palatinate illustrate the regional variance, as follows: Steep hills with a slope of more than $30 \%$ characterize the regions Ahr and Middlerhein, as $68 \%$ and $83 \%$, respectively, of their vineyards are steep. For the Mosel region, $42 \%$ of the vineyards is on steep hills. Nahe has about $16 \%$, whereas only $1 \%$ of Palatinate's and Rheinhessia's vineyards are classified as being steep [78].

Germany reports almost 45,000 wine growers, with $40 \%$ of that population stating wine to be their main source of income [79]. The industry experienced a drastic reduction in producers. Since the 1980s, more than half of the suppliers vanished (Figure 3). A significant decrease in producers, but a constant vineyard area, resulted in an increase in the size of the remaining wine estates. A larger size allows for the exploitation of economies of scale, with an increase in profitability [80]. In a pan-European comparison, German wine growers are stated to be leaders in productivity and profitability, despite the small size of the businesses [79]. Indeed, our surveys stated a constant performance increase across all success dimensions from 2012 to 2016. Still, there is room and a need for improvement, in order to increase profitability for a lot of German wine growers, in order to adequately compensate for family-member employment [43], imputed interests, and imputed entrepreneurial profit $[79,81-83]$. The wine estates' ambition to further increase the market size and profitability is jeopardized, as agricultural land prices more than doubled within the last 13 years [43].

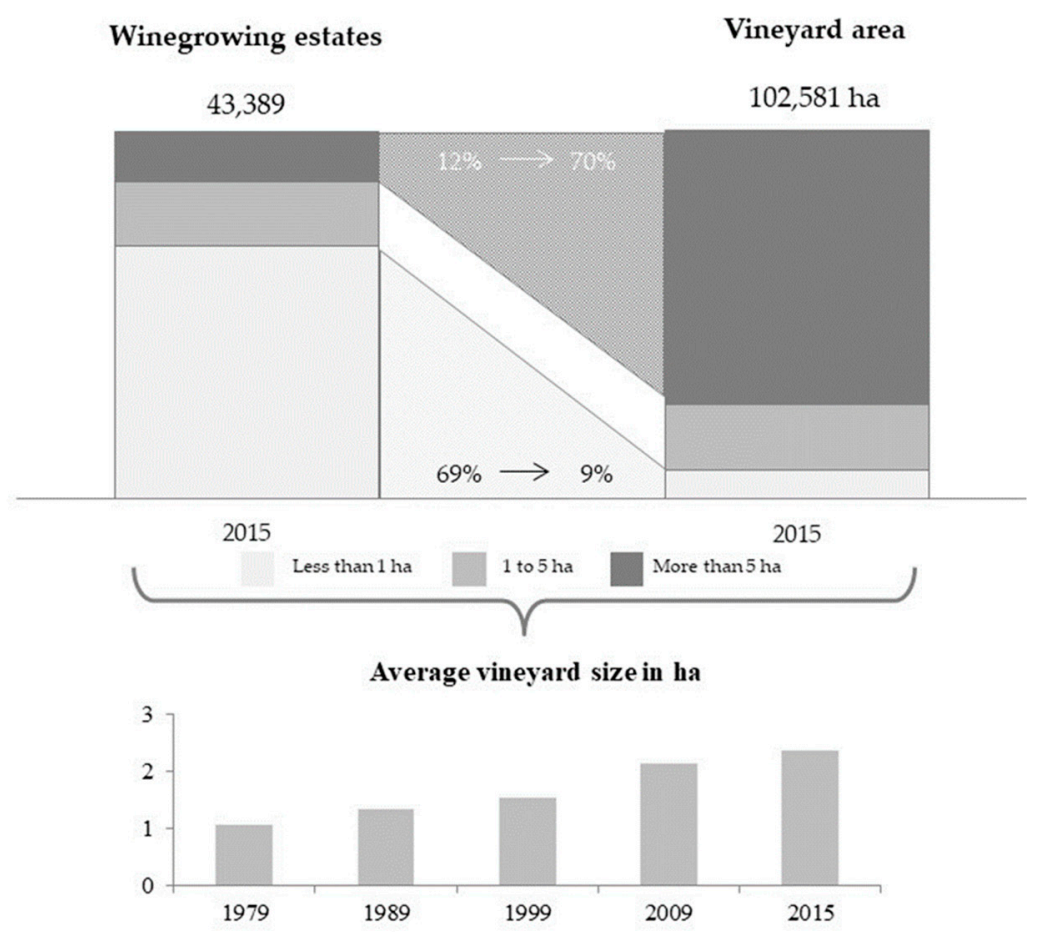

Figure 3. German wine production (number of producers and hectares) [70,79,84-87]. 


\subsubsection{Supplier Typology}

German supply of wine has been grouped into four clusters, by ownership, organization, and value-chain coverage, as follows: independent branded wineries, winegrowers, cooperatives, and wine cellars (Figure 4).

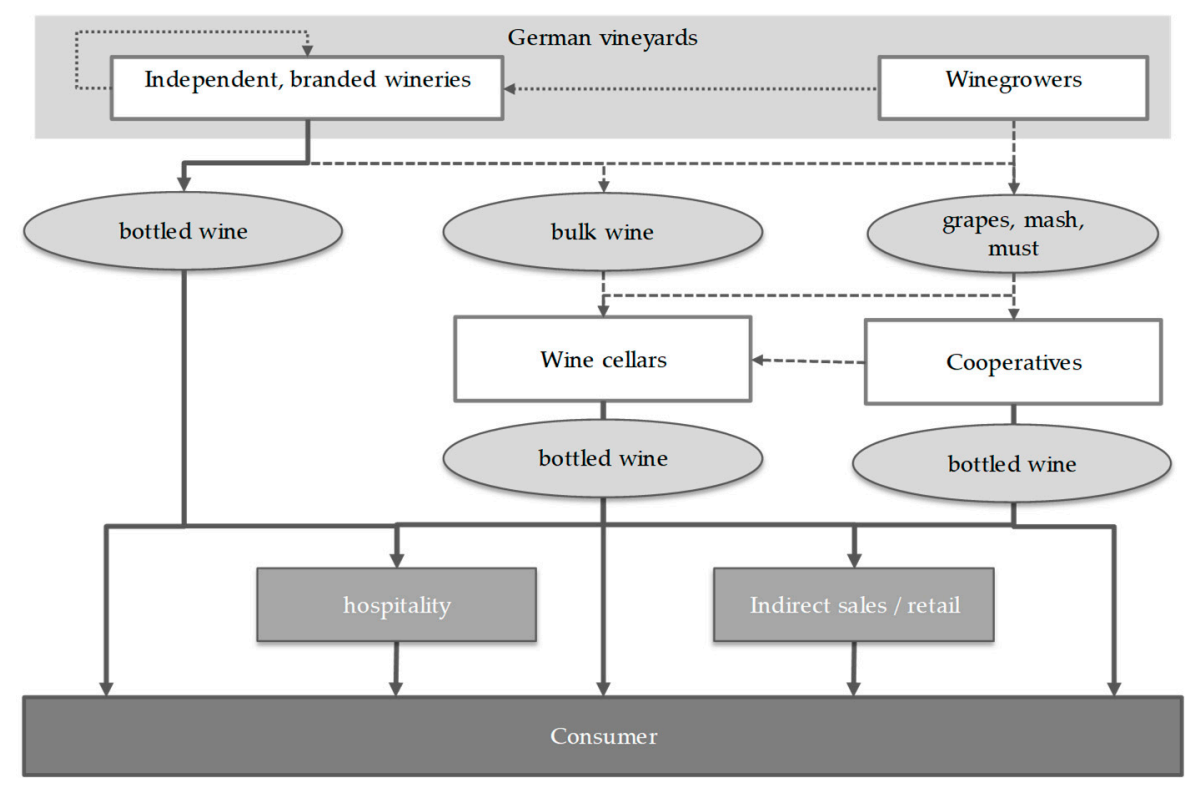

Figure 4. German wine supply (author's illustration).

More than 7000 entrepreneurial entities market as independent producers [57]. They represent predominantly family-owned entrepreneurial entities with a business model to produce and sell branded wine. On average, the production is on a surface of less than ten hectares, with not more than 150,000 bottles of produced goods per year, whereas the largest wine estates have an annual output of about 2.5 million bottles of wine [88-90]. The surveys indicate a strong tendency to reach a size of 25 hectares, realized by the tenancy of processing grapes or wine from third parties. Less than $10 \%$ are not family owned and non-family managed. Most owners follow the footsteps of their ancestors in taking over the wine-growing estate. More than $75 \%$ of the interviewed wineries are third generation or older, and only less than $5 \%$ are younger than ten years. Comparable studies in the United States showed $45 \%$ of the interviewed population to be established within the last decade [91]. The vintners selling bottled and branded wines cover the whole value chain, from planting, growing, harvesting, production, to marketing. To a smaller extend, independent winegrowers focus on cultivating grapes.

Cooperatives are joint ventures where winegrowers deliver their grapes to the collectively owned cooperative for production and sales [92,93]. Members plant, grow, and harvest, mostly with individual responsibility. Payment is on the delivered grapes. The origination of cooperatives dates back to the mid-nineteenth century, when producers faced severe profitability challenges because of low wine prices but high costs (e.g., rising interest rates). Cooperatives, as solidarity ventures, enable producers to share costs and build joint market power. The German wine cooperative Mayschoß-Altenahr, dating back to 1868, claims to be the oldest wine cooperative in the world [94]. The landscape of wine cooperatives has changed in line with the supplier restructuring (Table 1). Having peaked at around 1960, with more than 500 cooperatives and about 68,000 members, cooperatives contracted afterwards. Today, less than 200 wine cooperatives remain. A joint planting surface could be held at 28,500 hectares, as cooperatives predominantly merged $[95,96]$. 
Table 1. German wine cooperatives [84,93,95].

\begin{tabular}{ccccc}
\hline Year & $\mathbf{1 9 0 0}$ & $\mathbf{1 9 3 8}$ & $\mathbf{1 9 8 0}$ & $\mathbf{2 0 1 8}$ \\
\hline Cooperatives & 113 & 493 & 342 & 164 \\
Membership & 1000 & 29,000 & 67,000 & 49,000 \\
\hline
\end{tabular}

Wine cooperatives differ in size, membership, distribution, produced wines by varietals, and wine styles. The largest wine cooperative produces wine from more than 2000 hectares of vineyards $[97,98]$. Large cooperatives are able to supply indirect sales channels nationwide to market their products, whereas smaller cooperatives tend to rely on direct sales, similar to the independent wine estates [99,100]. The penetration of cooperatives varies by region. In Rheingau or Rhinehessia, less than $10 \%$ of the wine is produced by cooperative entities. Baden or Wuerttemberg produce and market almost four fifths of the regional wine production cooperatively (Figure 5).

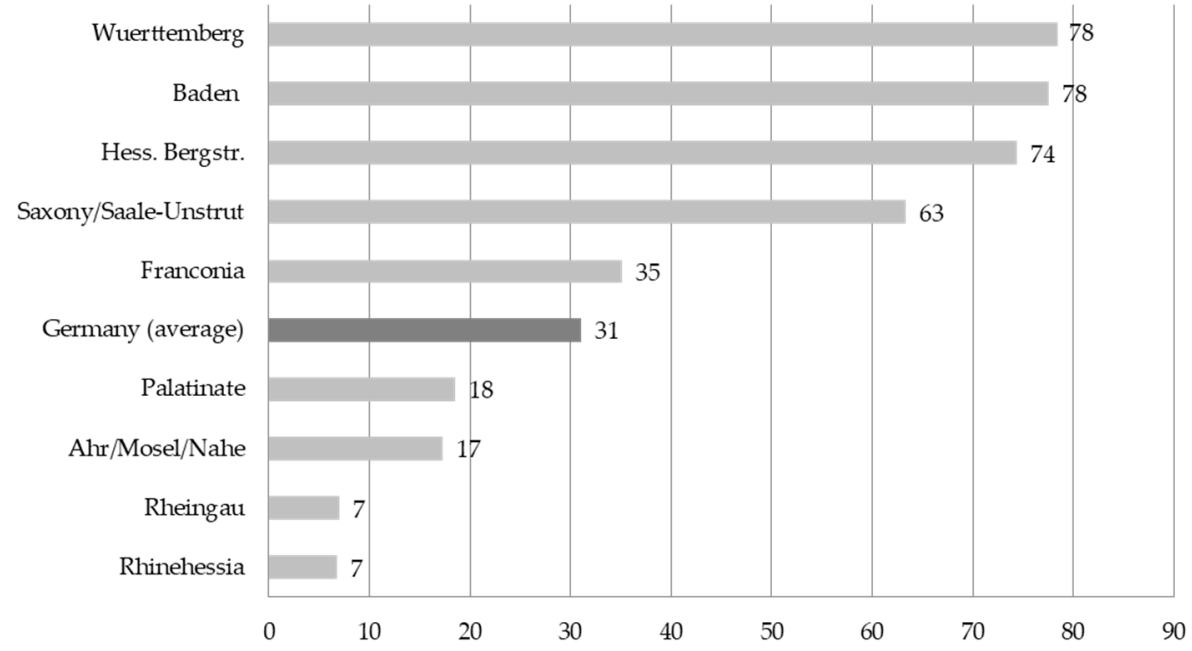

Figure 5. Regional penetration of cooperatives (\% of vineyard surface) [95].

The business model of wine cellars as predominantly larger wineries consists of buying wine or must so as to produce wine for the German market, as well as for export destinations. Jointly, the wine cellars market more than four million hectoliters of German wine [57,101]. The cellars possess large processing facilities, and given their high output, are capable of supplying national and global retail. The revenue of just the three largest wine cellars' combined exceeds 600 million Euros annually [102]. Cellars' business models stretch from spot market provision to a mix of permanent partnering with suppliers (e.g., independent vintners), as well as national and international bulk ware refinement [101,103].

More and more, the selective business model boundaries blur. Wine cellars create brands appearing as small, independent premium wine estates, or they acquire such brands. Independent wineries try to grow and win market share by acquiring competitors, long-term lease agreements, or third party supply. Often, successfully playing in the premium segment, they serve the basic wine market segments with a business model that resembles wine cellars. Cooperatives increasingly efface mutual belonging from their commercial name, establish wine brands to compete with independent wineries, or their members create a direct to consumer winery. Hence, strategic profiling serves to analyse the market structure.

\subsubsection{Strategic Positioning and Innovation Management}

The literature on strategic grouping for enterprises extensively explores which strategy to pursue in order to profile in the market, attract the customers, and exploit revenue and profits accordingly [104]. An ongoing academic discourse addresses the dimensions of strategic profiling [105] 
and the resulting groupings $[12,14,106,107]$. In academia and in practice, Porters' two-dimensional model [3,108-110] deciding on market scope and the primary source of competitive advantage is highly acclaimed [111]. Porter recommended that companies position themselves as either a cost leader, differentiator, or niche player [112]. Without a clear generic strategy, companies risk being "stuck-in-the-middle", with lower profitability.

The majority of the surveyed German wineries claim to be positioned on price-value-strategy or quality leadership, which are jointly pursued by more than three fourths of the population [113] (Figure 6). A premium strategy follows next (12\%). Niche strategies [114] build the generic orientation for $10 \%$, whereas cost leadership is used by only $2 \%$ of the interviewed population. Product-centrism hence dominates the strategic profiling of German wineries [50]. The revenue generation of the wineries is wine focused. Of the wineries, $80 \%$ state that wine sales determine $90 \%$ or more of their revenues. An obvious reluctance with regards to niche strategies illustrates the market inherent uncertainty [76]. In contrast, the German brewery industry is much more niche oriented [115].

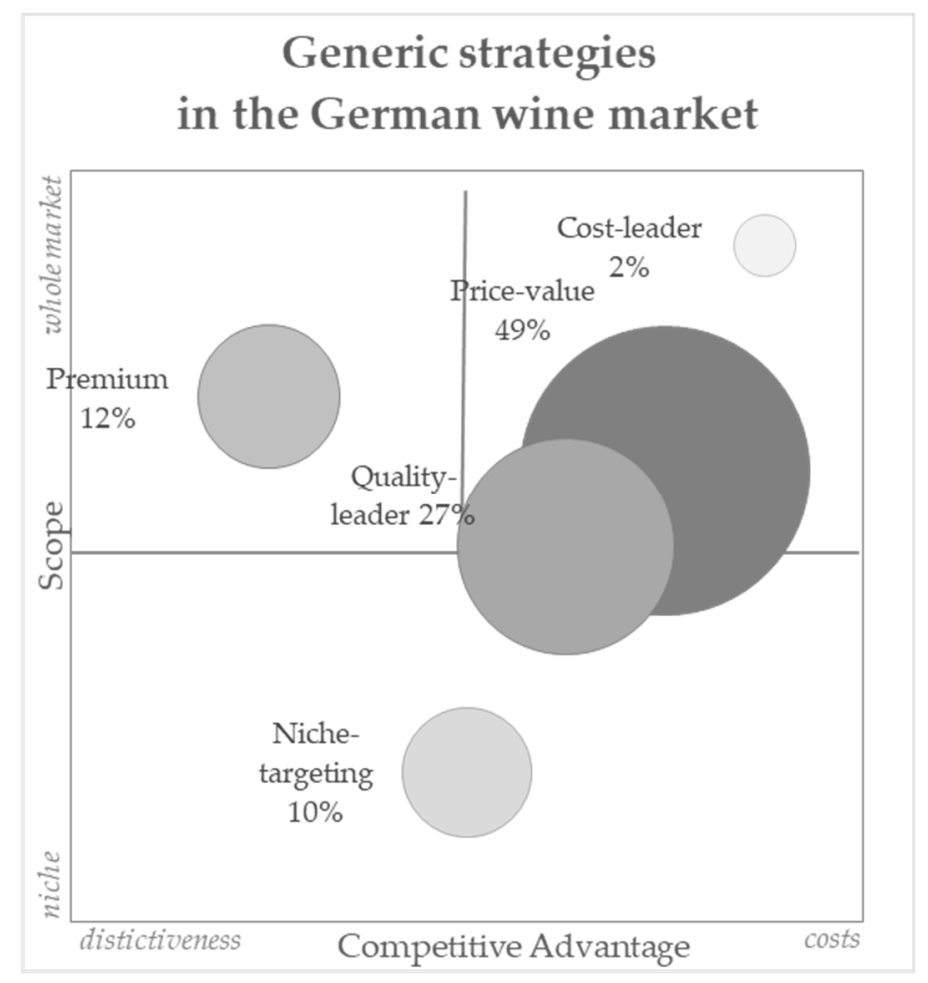

Figure 6. Strategic landscape of the German wine industry (survey results).

Differentiation and innovation play a pivotal role in competitive fragmented markets [116,117]. Service innovation and value-added services allow for winning or keeping customers in competitive markets [118]. The empirical wine data supported the general business perception of a high relevance of innovation, as follows: premium strategists outperform on customer-oriented innovation. Positioning via niches delivers the best results on service quality and new customer acquisition. Business literature advises increasingly offering solutions instead of products [118,119], and pursuing niche-based value-adding strategies in order to differentiate in the market and to win the increasingly demanding customers [120-122]. Indeed, the premium and niche clusters scored high on creativity and innovation, succeeding in turning value-added offerings into profitable business [123]. In line with the prior empirical findings, the innovators or regional niche players were rewarded by a superior economic performance [124]. Cost leaders concentrate on straightforward offerings. Their innovation is production centred so as to optimize and further gain efficiency. This strategy proves less promising for winning new clients in the fierce competition in Germany. Moreover, the strategic groupings decide 
on the aspired price levels of the wineries, but even in the premium grouping members struggles with enforcement.

Wine producers face a complex and challenging market, but with opportunities for value creation. Indeed, new market entrants prove the German wine supplier market to be attractive, and the recognition for the product as well as the entrepreneurs in that industry is high-a rewarding utility. The observed strategic groupings show that product-centrism still prevails with rather close than distant profiling to competitors. In case of orientation towards premium wineries, such strategic behaviour nourishes the hope for legitimization, with profiting higher prices or quality awareness. "Stuck in the middle wineries" lack profiling, as quality is a hygiene factor and is expected from all suppliers. A lot opportunities for success and entrepreneurship exist [76]. An ecological strategic positioning can consist of a combination of biological focus and premium strategy $[125,126]$ also allowing for integrating the renaissance of traditional cultivation with modern appearance and design [127]. Increasingly, the notion of sustainability allows for strategic profiling integrating ecology, economy, and societal goals, and secures resilience in a competitive wine industry [128]. Indeed, of all of the surveyed strategic measures, sustainability gained the highest momentum. Sustainability engagement furthermore depends on strategic grouping, with for example, the highest relevance for niche strategists and the least for cost leaders.

\subsubsection{Environmental Perception}

The industry analysis and organizational adaptation builds on understanding the environmental forces $[16,24,107,129,130]$. The empirical data retrieved by the strategy surveys disclose as prime environmental issues that German wine producers sense bureaucracy, changing customer behavior, societal responsibility, and climate change. Thus, the surveys indicate that the perceived challenges in the German wine business differ from what the managers of other industries face. Pan-industry, top three challenges consisted of intensified competition, increasing complexity, and economic uncertainty [131], all ranked at the end for the wine-specific studies (Figure 7).

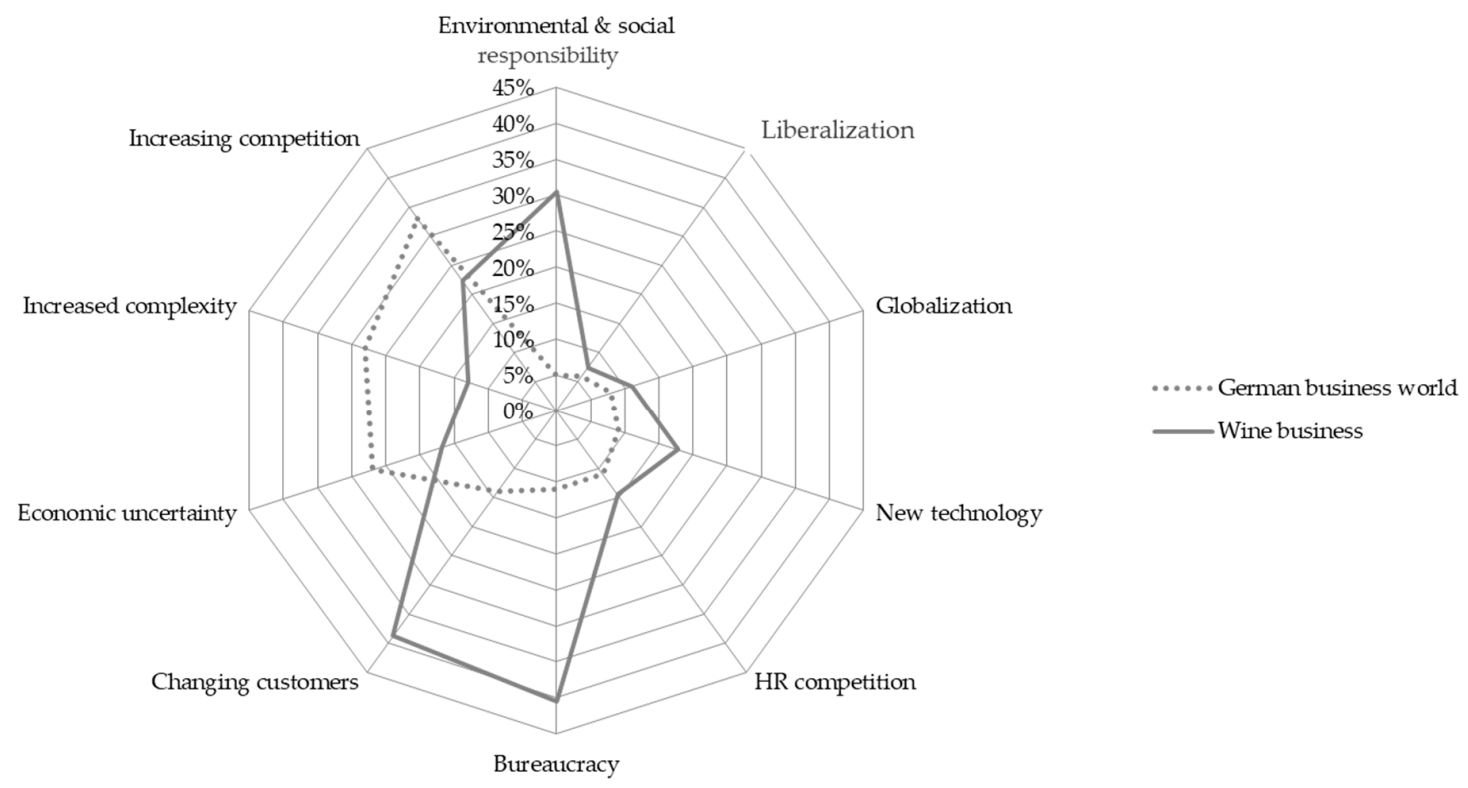

Figure 7. Environmental perception (survey results [131]).

Comparing the environmental perception surveyed in 2018 to 2012, the relevant driving issues remained, but with a change in their order, as follows: climate change climbed to number one, the changing consumer behavior remained in second place, and bureaucracy switched to number three. Additionally, pressure to become more profitable increased significantly. Overall, German viti- and vini-culteurs recognize the changing customer demands, also resulting in vanishing 
customer loyalty [132]. Changing consumer preferences [72] require new marketing and channel approaches (e.g., internet sales, blogs, online auctions, etc.) on the basis of a strategic path and with adequate investments [133], stated in the course of the interviews. Vintners recognize the ecological environment in their daily operative business with more volatile and often devastating weather extremes $[68,134]$. Obviously, wineries suffer from restrictive bureaucracy in their need for flexibly to react to environmental changes. As a result, the challenges of winegrowers and vintners in Germany are various, and their complexity is increasing with a need to deliver high quality, sustainable production, with consistency and openness for trends despite regulation and bureaucracy.

\subsection{Demand Perspective: From Wine Consumption to Reaching Consumers}

\subsubsection{Wine as Product Category within Beverages}

German households spend about $14 \%$ of their income on food and beverages [44]. Alcoholic drinks' "share of mouth" in the segment of beverages accounts for $18 \%[55,135,136]$. Beer is making up to almost $80 \%$ of alcoholic drink consumption, whereas wine stands for $18 \%$ [87], so Germany is generally characterized as a beer drinking society. This perception finds support in an overall low alcohol abstinence (below five percent) $[137,138]$, with just less than one fourth of the German drinking-aged population denying beer consumption [139], but 35\% of Germans stating to refrain from drinking wine [140]. Nevertheless, the share of wine in spending for alcohol drinks exceeds $40 \%$ [55]. Indeed, Germany represents a voluminous wine market. German wine consumption of more than two billion liters annually represents $8 \%$ of the global wine production [1]. Wine consumption climbed to a level of $24 \mathrm{~L}$ per capita, compared with $17 \mathrm{~L}$ in 1970 [40,141]. Furthermore, Germany takes a pole position in sparkling wine. More than $20 \%$ of the global sparkling wine production is consumed in Germany [142]. Given the overall declining alcohol consumption in Germany [2,143-146], but the continuously stable wine consumption (Table 2), tells of the substitution of other alcoholic beverages [33,147] despite significantly lower advertising. Wine makes up for only $3 \%$ and sparkling wine for $13 \%$ of the alcoholic drinks' annual expenditures on advertising [145,148,149], with drinks ranked in position at ten of the German industry advertising spending [150]. Wine is frequently interpreted as part of a modern style of indulgence and stylish alcohol consumption [151].

Table 2. Average per capita consumption alcoholic drinks in Germany (2002 vs. 2016) [55,152].

\begin{tabular}{cccc}
\hline Consumption by Category & $\mathbf{2 0 0 2}$ & $\mathbf{2 0 1 6}$ & $\mathbf{1 6}$ vs. 02 \\
\hline Spirits & 5.9 & 5.4 & $92 \%$ \\
Sparkling wine & 3.9 & 3.7 & $95 \%$ \\
Wine & 20.3 & 20.6 & $101 \%$ \\
Beer & 121.9 & 104.0 & $85 \%$ \\
Total & 152.0 & 133.7 & $88 \%$ \\
\hline
\end{tabular}

\subsubsection{Consumer Preferences in Wine}

Looking at a drinking frequency of once or more in a week, beer takes pole position with $43 \%$ of the population stating such a drinking intensity-for wine it is $16 \%$. But more than $50 \%$ of the German wine drinking population enjoys wine at least two to three times per week [153]. Sparkling wine is an occasional drink for celebration [154]. Consumers prefer German wine and red wines $[155,156]$. Preferences for dry wines constitute about $30 \%$, semi dry $45 \%$, smooth $51 \%$, and sweet wines $27 \%$ of the investigated German wine population (multiple answers) [157]. Accounting for drinking intensity, the preference for dry wines increases to $43 \%$ of the volume consumed [158]. The consumer preferences have changed over time, as exemplified by the split of wine color, as follows: In the mid-sixties, $75 \%$ of the total consumption was white, $24 \%$ red wine, and $1 \%$ rosé wines [159]. In 2016, red wine consumption represents $47 \%$, white wine $43 \%$, leaving $10 \%$ for rosé wine [160]. More than half of the wine consumed in Germany is imported [161], despite home production (Figure 8). 


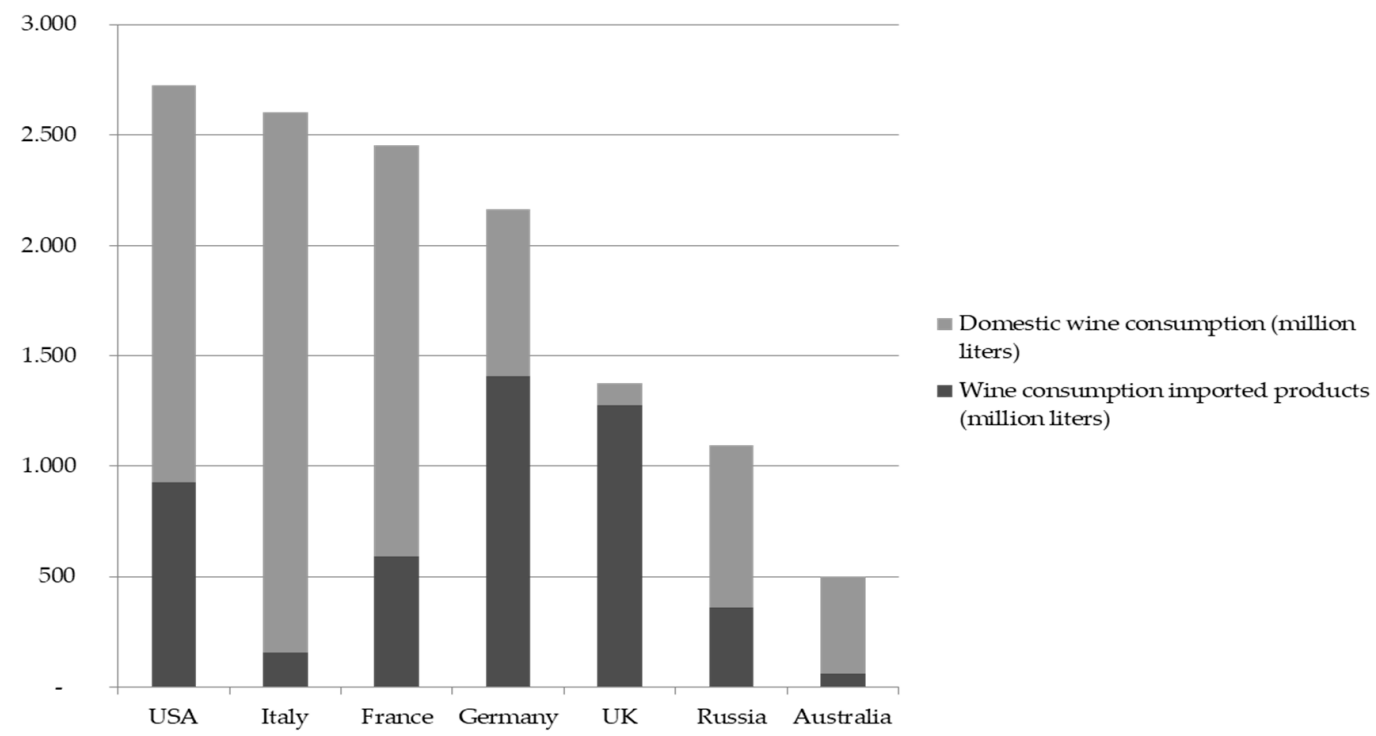

Figure 8. Global comparison of wine consumption and import penetration [143].

German consumers select wine and define quality on grapevine variety, origination, price, and brand [162,163]. Brand-and therefore reputation-in light of wine possessing emotional utility constitutes an important decision making factor determined by individual (e.g., brand of the producer) and collective (e.g., region of production) effects [162,164]. Moreover, market research revealed that German wine consumers among other perceptive factors associate French wines with prestige, Spanish wines are chosen for red color and good price-value relationship, and Californian wines for design [165]. There are numerous possibilities to cluster the consumers and their wine buying behavior ranging (e.g., income, wine style, region, age, consumption intensity, behavior, involvement, etc.) [166,167]. For wine, situational segmentation provides additional orientation, as drinking occasions influence the buying decision; buying wine as a present or ordering wine in a restaurant with accompaniment impacts the choice of wine compared to solitary home consumption $[168,169]$. Over the years, modern norms and values became more prominent in German society, with an influence on wine preferences [170]. A shift from status orientation centered around traditional Germanic values towards modernity and lifestyle characterizes this evolution [171,172]. In a 20 year timespan, curiosity for new experiences in wine showed the highest increase, and loyalty to known brands highest decline in attitudes [173].

Not to be neglected, regional characteristics are decisive. Residents of non wine-growing areas with a subsequent stronger penetration by indirect channels are more exposed to international products. Indeed, in North-Rhine Westphalia, the wine drinking population is characterized by a lower average consumption of wine and a preference for foreign products [174]. On the other hand, in Baden or Württemberg, as regions with wine production, wine drinkers consume more wine than the German average, with preference for German products [136]. Wine drinkers in the south or west of Germany are more interested in wine. In North-Rhine Westphalia and Bavaria, consumers rely on specialized wine stores, and in the south, they are aiming for more variety [158]. In regards to sparkling wine consumption, Eastern Germans are above average [174]. Overall, German wine profits of the trend for regional products $[175,176]$.

\subsubsection{Reaching the Consumers: Distribution and Channel Perspectives}

Wine consumption patterns and occasions in Germany are diverse. Of the overall two billion liters of annual wine consumption, sparkling wine represents 16\% (Figure 9). Approximately 85\% of the remaining 16 million hectoliters of non-sparkling wine is bought off-premise for consumption at home. Two different buying phenomena split home consumption. Either consumers wish an 
experiential buying, or wine is just part of the recurring grocery shopping activity. In the course of grocery oriented buying intention, supermarkets and discounters supply the demanded wine with a nationwide coverage of about 35,000 outlets [135,150], heading a density of outlets in Europe with Austria $[177,178]$. Retailers, discounters, and supermarkets thereby supply more than $70 \%$ of the wine consumed in Germany. Germans also enjoy wine in restaurants, bars, or at events. Indeed, Germany celebrates numerous regional or local wine festivals-more than 270 events per year are declared pure wine festivals [179].

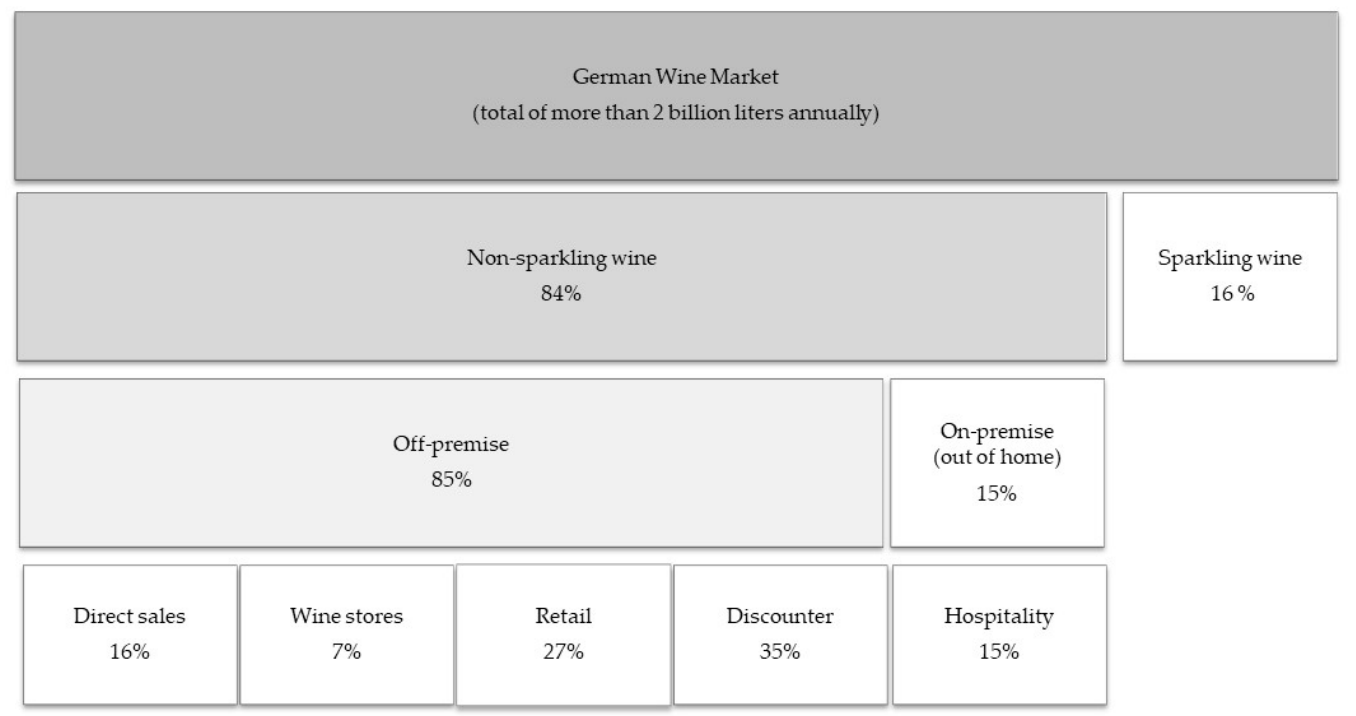

Figure 9. Wine market distribution: reaching consumers [55,72,160,174,180,181].

Indirect channels are efficiently building bridges from producers to customers. Supermarkets, discounters, and specialized wine retail stores are the prime institutions for nationwide coverage and indirect supply. Thus, supermarkets and discounters are increasing their market share. Although wine from a value perspective represents only a minor category in their offering, standing for only $2 \%-3 \%$ of retailers' sales [135], wine is increasingly used to position in the market and to attract customers. The assortment variety and depth can be substantial, with retailers' sales outlets offering more than 1000 different wines. The "mass buy" phenomenon, with wine predominantly belonging to the daily grocery shopping, makes up for three fourths of the wine sales, and more than $85 \%$ of the imported products sells via supermarkets and discount channels. Retail negotiates discounts for the wine supply ranging from $25 \%$ to $50 \%$, to cover costs and safeguard a margin. The power of supermarkets and discount chains increases with ongoing retail concentration $[178,182]$. Indeed, one discount market chain in Germany by itself has a market share of more than $27 \%$ for wine within the indirect channels, offering wine with an average prices of less than $2 €$ per bottle [183-187]. Indirect sales in conjunction with imported products' increasing competition are hence declared as the main reason for the low-price levels of wines. Retail sells wine for about $2.92 €$ on average per liter [160,188]. International comparisons confirm low price levels in Germany for wine, and the high price sensitivity of German consumers. [137,182,189,190]. Germany builds the bottom end with the highest share of low priced products, and also because of a modest market growth but a voluminous market, it qualifies as a global "cash cow" [191].

Possessing the means to buy wine and channel preferences correlate with wine knowledge and interest. More premium wine oriented groups show a more sophisticated approach to wine and spend more on wine $[158,192]$. Segments belonging to the basic wine consumer groups spent in between 65 to 100 Euros per year, and despite jointly covering $58 \%$ of the overall wine drinking population, they only consume $36 \%$ of the wine, served by indirect sales channels. Here, consumers decide neither on advice nor on tasting the products. In such buying situations, the decision is mainly 
directed by price, origin of the products, packaging, and design [193]. For experience sales with higher emotional utility, the buying decision is different, given the opportunity to taste the products and the chance of the seller to steer the buying decision in the course of the sales process. Indeed, price in the wine business is not only relevant with regards to price elasticity. Consumers connote higher quality in cases of more expensive wines [194]. The quality of wine certainly matters [166,195-197], but as wine is an experience good [198,199] with information asymmetries between the producer and the buyer [200-202], consumers' quality judgements are limited [203,204]. Moreover, wine varies yearly because of seasonal vegetation and volatility in the wine making process, so historic product experiences do not guarantee identical future ones [205]. As a result, wine consumers feel limited in their capability to assess quality [206-211]. Symbolic criteria such as aesthetics, status, or taste substitute functional quality determination $[169,212,213]$. Customers rely on the reputation of the producers [214-217] to reduce uncertainty, diminish assessment costs, and raise wine quality perception [218-220]. Indeed, given the emotional utility of wine, prices strongly depend on reputation [221].

In case of "experience shopping", demand is either satisfied by the wineries themselves or by one of the more than 4000 specialized wine stores [222]. The direct sales of producers to end consumers makes up for more than $15 \%[55,72,87,160,180,223,224]$. Taking into account higher prices and selling premium products, the "value buy" share with wine centric shopping and an emotional buying intention makes up for about one fourth of the German wine market in sales volume, generating almost half of the monetary volume of the wine market [154]. Traditionally, direct sales are important for German vintners, allowing for attractive price levels and direct contact to the customers. Not only direct sales, but also a mix of sales and on-premises consumption characterizes the offers of German wine producers. Seasonal wine rooms, known in the diverse wine regions under varied names (Besenwirtschaft, Straußwirtschaft, Heckenwirtschaft, etc.), have developed in attractive restaurant offers $[47,52,225]$. Together with wine festivals and local events, it is a great opportunity for producers to interact with the customers to increase loyalty and retention, and to acquire new customers [226]. While it is still common that consumers pick up at the winery or viticulturists deliver it personally to their customers all over Germany, retail is gaining ground (Table 3).

Table 3. Calculated market share direct vs. indirect wine sales $[55,72,87,152,227,228]$.

\begin{tabular}{ccccc}
\hline & \multicolumn{2}{c}{ Volume Share (L) } & \multicolumn{2}{c}{ Revenue Share (€) } \\
\hline Channels & 2008 & 2016 & 2008 & 2016 \\
Direct sales wineries & $16 \%$ & $13 \%$ & $25 \%$ & $22 \%$ \\
Indirect sales channels & $84 \%$ & $87 \%$ & $75 \%$ & $78 \%$ \\
\hline
\end{tabular}

Direct buyers are highly appreciated by producers, as product prices without discounts at lower costs of distribution can be achieved. There is a risk of a dying population in that channel, as the average age of that customer segment exceeds 60 years. Wineries with a strong penetration of direct buyers need to take strategic measures to secure future market success. Furthermore, decreasing customer loyalty and diminishing order values are symptoms of behavioral changes to be considered as well [132]. Optimizing web pages, creating online-shops, building interactive wine experiences, offering events, or special tastings, but also investing in their show rooms are just few examples of efforts to increase loyalty or attract customers-hence, the wineries deliver to ameliorate the customer buying experience [226,229].

Customers are also willing to pay higher prices for on-premise consumption. Restaurants use wine as an opportunity for revenues, winning new customers, increasing loyalty, and margin contribution. Wine subsidizes food sales. A multiple of 3.8 to 4.5 on the purchase price is applied for wine, compared to 3.3 to 3.7 for food [230]. For on-premise channels, imported wine is substantial. Surely, in case of offering country-based food (e.g., Italian, French or Austrian restaurants), the wine portfolio is dominated by wines from the country origin. High-end restaurants serve nationally and internationally 
recognized wines, especially icon wines from Bordeaux, Burgundy, or Italy, but unspecified restaurants also have international products on the wine list. For the wineries, these sales channels are relevant with regards to sales (Figure 10) but also as means to build reputation [231]. Increasingly, the value of regional clusters with wine producers actively supporting the sales in restaurants is discovered. Winemakers support the restaurants offering wine tastings or providing insights into their served wines at dinners, or by training the service personnel. Cooperative behavior and cluster initiatives of wine and tourism foster such active partnership, with a positive impact for German wine [112,195]. However, the substitution of on-premise by increased home consumption-in 2000 on-premise sales were reported at $23 \%$ of the overall market demand, today they are at about $15 \%$ (explained by price increases of restaurants with the introduction of the Euro and later with increased price sensitivity as a result of the financial crisis) is forecasted to endure [230,232].

In line with the general consumer attitude to increasingly buy online [233-235], online offers for wine are gaining ground $[72,150]$. In our realized surveys, wineries claimed on average more than $5 \%$ of sales to be realized online (Figure 10), in line with current market research $[235,236]$. Still, one third of the participating population of wineries stated to refrain from online sales activities, but for several participants, online sales accounted for one fourth of their sales.

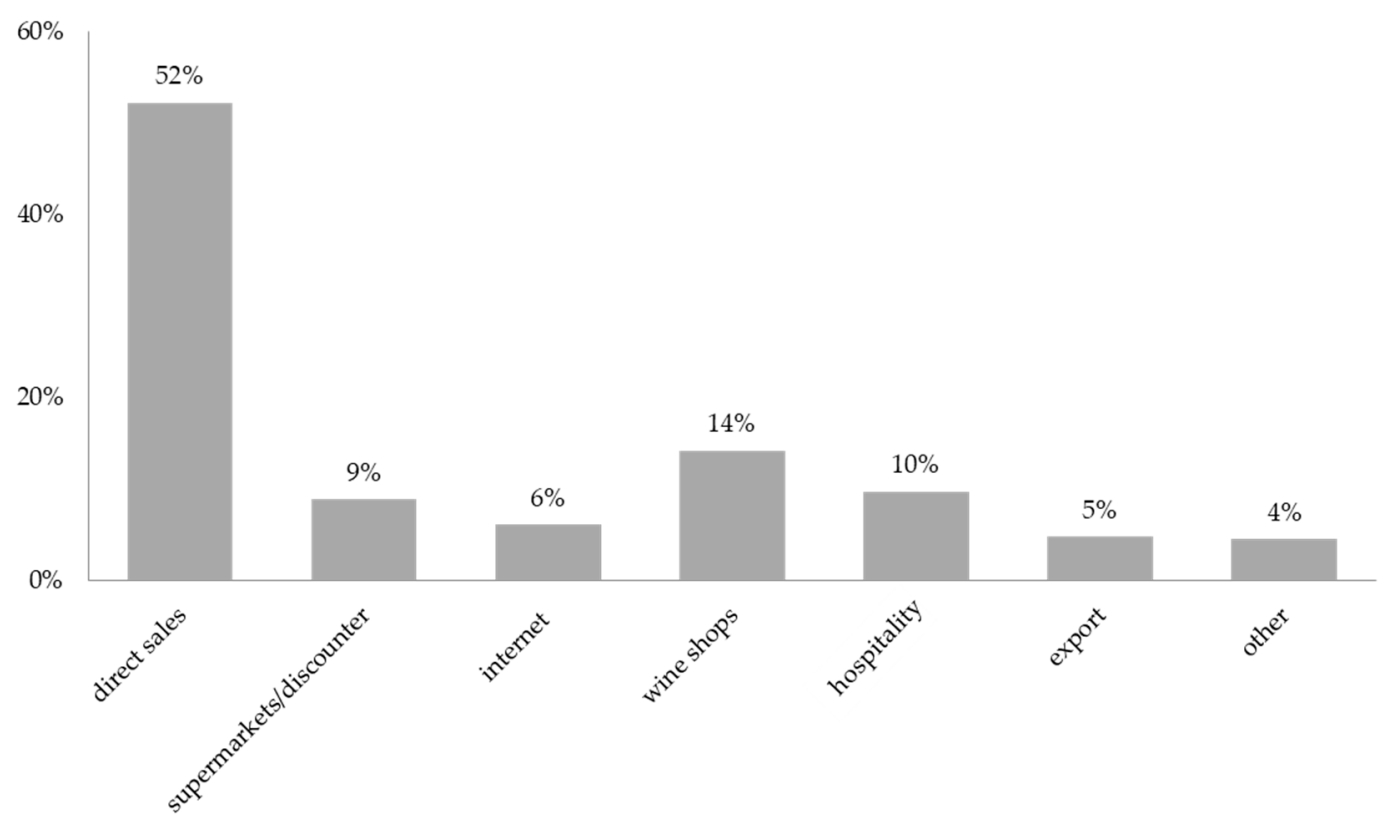

Figure 10. Average revenue contribution of German wineries by sales channel (survey results).

The realized surveys underline the relevance of the following:

(a) direct sales to consumers: all participants stated to actively serve their customers directly;

(b) sales to restaurants being of relevance in importance in volume sold (exceeding perceived relevance by secondary market research), but also being a lever for brand communication;

(c) specialized wine retail to serve for the distribution of more premium product ranges; and

(d) online sales to grow and split the wine estate population [133].

\subsubsection{Sparkling Wine-A Specific Segment in the German Wine Market}

With a volume of about four million hectoliters annually, sparkling wine is a substantial component of the German wine market. This market segment differs in supply and consumption from non-sparkling wine. Few suppliers with strong brands dominate the market. Brand recognition determines $80 \%$ of sparkling wine buys [237]. Sparkling wine producers therefore invest in advertising, communication, and additional marketing activities. Sparkling wines predominantly sell by indirect 
channels (supermarkets, retailers, and discounters). Retailers use sparkling wines as a primary teaser to attract customers into the shops [142]. As a result, almost half of the sparkling wine volume sells via intensively advertised promotional offers [238,239]. The market segment of sparkling wine splits into about $80 \%$ home and $20 \%$ imported products, with German brands consisting of internationally supplied bulk wine. Less than $10 \%$ of the products stem out of grapes grown in Germany. Although more than 1300 suppliers-including small wineries—serve the German sparkling wine market, the seven largest producers jointly have a market share of more than $85 \%$ [142]. The high concentration contrasts the fragmented still wine market.

Sparkling wine consumption suffers a decline in consumption and substitution, within the following [239]: Sparkling mix products and non-alcoholic drinks are gaining ground, a trend that the beer industry has been facing for years [72,224]. Product innovation therefore serves to outgrow competitors in a stagnant market [237].

\subsubsection{Market Volume, Growth, and Implications for Suppliers}

Consolidating the market information from the perspective of German consumers' spending on wine the total market volume exceeds twelve billion Euros annually. This calculated market volume accounts for the prices paid for on-premise wine consumption, and includes the sparkling wine segment. Future market growth seems limited, as penetration decreases and because of German demographics. Whereas in 2005, more than $64 \%$ of the German households stated buying wine, the penetration plunged to $56 \%$. [72,160,184,227,239]. Furthermore, the German population is expected to decrease [240], not signposting a dynamic market growth. Additionally, the megatrends for a more healthy lifestyle and more environment conscious consumption have implications on food and therefore also on wine $[176,241]$. With lighter and healthier food, accompanying wine profiles are sought after as follows: fresh and fruity wines, easy to drink, and not complicated. This change of wine style preference reflects a change in the society. Modern households provide less storage place and wines are therefore consumed without time in their own cellars. Hence, wine is consumed earlier, often immediately after buying the products. Trends influence consumption, buying behavior, wine styles, but also planted varietals to serve consumer preferences. A multichannel approach is characteristic of the population of modern affluent, and optical aspects to draw the attention of this segment are of paramount importance [230,242,243]. Our surveys illustrate the multichannel activities of the German wineries (Figure 11). In contrast to other studies [57], our statistical analysis manifested that multichannel approaches are not only relevant for larger suppliers.

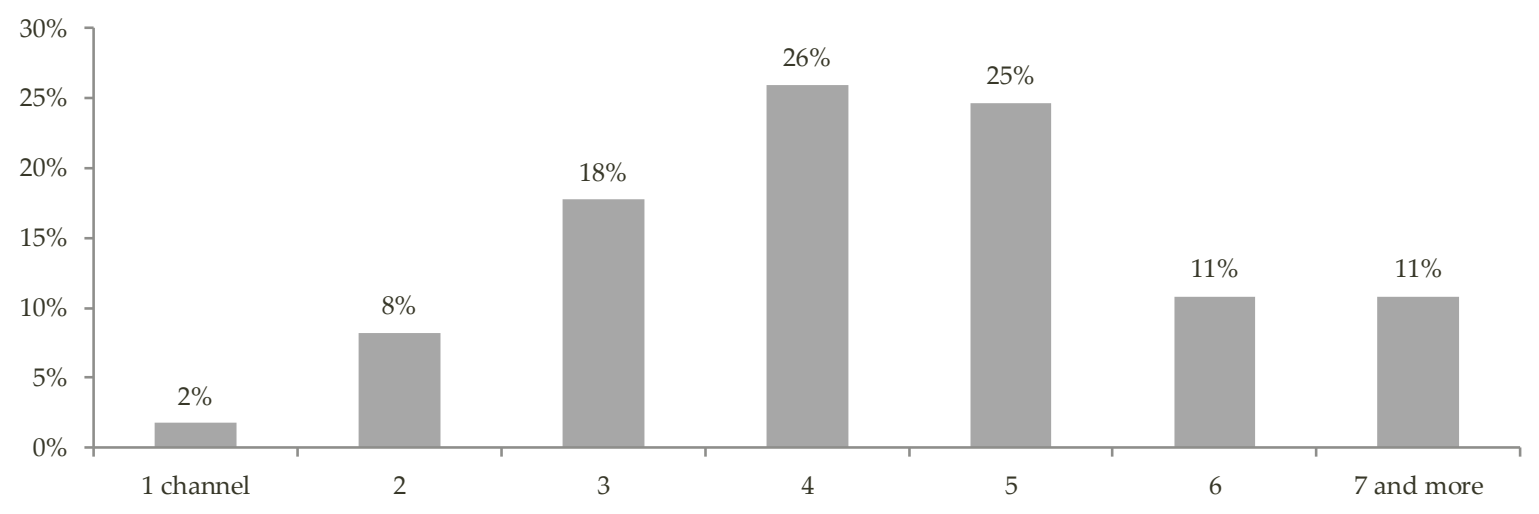

Figure 11. Multichannel activities of German wineries (average distribution channels, survey results).

The trend towards ecological and sustainable behavior also affects the wine market [244]. Ecological wine gains in market share, although penetration is less than for ecological or organic food $[125,137]$. Sustainable and biological or biodynamic production also serve in communication and profiling of the producers. For wine, the trend towards regional products seems of even higher importance than sustainability claims [176]. Consumers feel more trust in the producer and the 
proximity of production. Additionally, regional consumption reduces logistical efforts, and therefore increases sustainability. Moreover, while direct sales profit on the trend for regional products, it also affects the indirect sales [245]. The retail shelf place of local producers is expanded with regional product zones in the supermarkets [235].

Forecasts for the German wine speak for $1 \%$ of the annual growth in market value, but a slightly decreasing market volume [228]. Hope prevails that the premium wine segments will outgrow the lower ones, supporting more proliferation of premium wines in Germany [246]. The price premium for domestic products might further increase, a potential signal that German products are gaining in quality [232]. Indeed, offer adaptation allows for profiting from market trends, as for example for the sparkling segment rosé sparkling wine, alcohol free sparkling, or mixed drinks with sparkling wine.

\subsection{Import and Export Perspectives}

The German wine market serves nicely as example of globalization. While the focus of this section is on wine trade, there exists supplementary international economic activities besides wine shipment such as supply material (e.g., yeast or fertilizers), consulting, and wine tourism.

\subsubsection{Germany as a Longstanding Wine Import Champion}

Germany is the world's leading wine import country [1], with 15 million hectoliters and 2.3 billion Euros in value per year, followed by the United Kingdom, and with a wider gap by the United States of America, all three countries importing more than 10 million hectoliters of wine [2,55,247-249]. Despite the strong import activity of the United States of America, its per capita import in comparison to Germany is tiny. For forty years, Germany has led the global wine imports ranking [250]. Two thirds of Germany's imported wine is delivered as bulk wine [248,251], serving the production of sparkling wine or for being processed, often for exportation. With regard to country of origin, three main countries, Italy, France, and Spain, constantly battle for leadership, with Italy having a strong lead. Those three European suppliers jointly cover three fourths of the imported wines in Germany in volume and value terms [55,249] (Figure 12). The German import pattern reflects the global situation, with Italy being champion in volume terms and France having a lead considering their price levels and volumes in export [173].

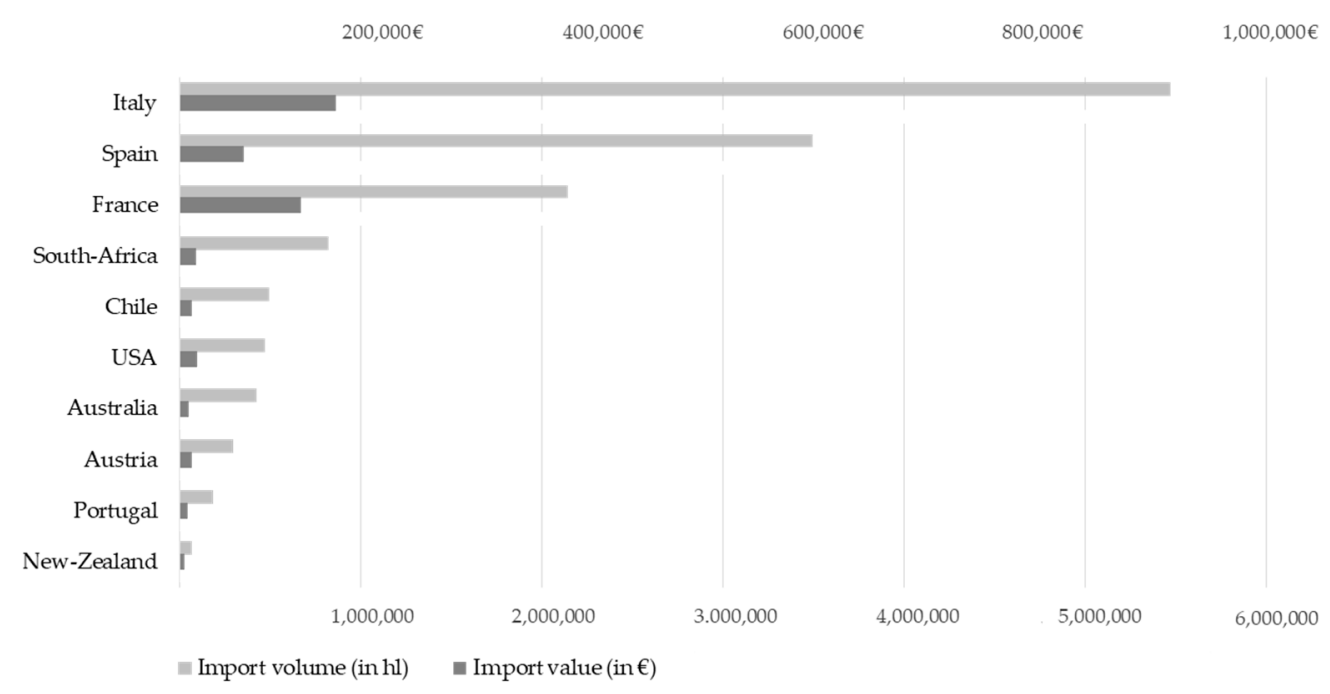

Figure 12. Origination of imported wines (2016) [55].

Foreign country bottled wines find their way to the German consumer predominantly by indirect channels $(85 \%)$ or on-premise consumption $(15 \%)$. New world wines have strongly penetrated the market reaching about $12 \%$ of the market share. Despite very different paths for each country, and also substitution within the new world wines' portfolio [161,252], they are highly appreciated by the 
discount retailers with an excellent value at an attractive price level (2.50 to $3.30 €)$ they apparently offer [253].

\subsubsection{Export Performance}

Statistics report 3.5 million hectoliters of wine leaving the German country for foreign markets [55]. Given the export volume of Spain or Italy, each exceeding 20 million hectoliters, Germany is a rather small player [141], but ranks within the top ten of wine exporting countries [1]. This represents an impressive growth since the turn of the century, but the global wine trade has outgrown Germany's export increase, and in value terms even doubled with $40 \%$ of the wine produced globally crossing national barriers [2]. Moreover, just about one tenth of the German wine export is grown and produced in Germany, whereas in 2000, more than eight tenths of the export was German wine (Figure 13). Obviously, Germany has developed as a hub for international wine production and distribution $[57,254]$.

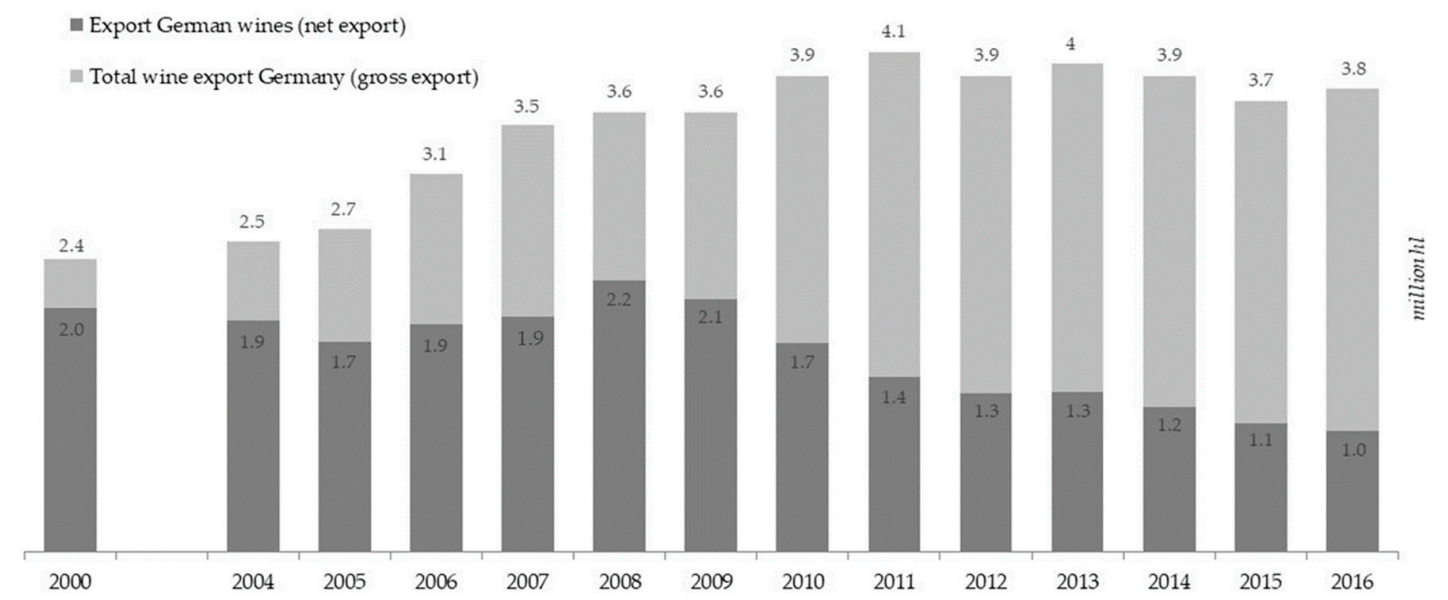

Figure 13. Wine exports (in million hectoliters).

Prime destinations for German wines are the United States of America, the United Kingdom, and the Netherlands, with the United States of America showing a high price level in comparison with the two other destinations [55]. Those three destinations make up for more than one million hectoliters of exports. Scandinavian and Asian countries are highly attractive for German suppliers, owing to the price levels that German wines are capable of realizing for those destinations $[255,256]$. Particularly China, with the projected growth in wine consumption, draws a lot of attention from German producers, despite the challenges to sustainably conquer that market [250].

A decrease in net exports is claimed to be the result of the low yields in the years 2009 to 2016. Given the below average harvests, German producers were forced to prioritize with the need to fulfill their agreements with retailers to avoid penalties or even lose the retail shelf place that was gained in tough competition $[133,257]$. Furthermore, loyal clients in direct sales were in focus in order to keep relationships. Less German wine was stated to be left for export. A survey on export success factors in the wine industry also evaluating the performance of German suppliers manifested that there is not a lack of competence. The questionnaire tested a success factor framework [32] with the four success factors export commitment, export knowledge, export strategy, and export promotion program. For each success factor, the addressed wine experts were asked to judge on the basis of six to seven criteria, on the relevance of the levers for the wine industry and the performance of German producers on a five-point scale. The results expressed a heterogeneous performance of German producers comparing the success factors, but a homogeneous performance for all of the underlying criteria within each success factor [258]. German suppliers scored well on all success factors, with the highest recognition for their export knowledge (Figure 14), but a performance gap for the success factors export commitment and export strategy, where German wine producers' performance lagged 
the perceived importance. The German performance level above acknowledged importance in export knowledge reflects a cultural characteristic - here, to avoid uncertainty [259-262].

The interviewed experts judged export programs of importance and stated that in the case of Germany, providing the needed level of support and activity. Indeed, Germany's wine export organizations engaged to change the global perception of Germany, transitioning from former a profile of sweet and cheap wines, to now representing modern and highly attractive quality wines [255,258,263]. Quality awards and highest recognition not only for Riesling, and a positive trend in wine export prices illustrate success of the quality positioning efforts $[55,87,254]$. Still, the magnitude of export support of the competing wine countries found a competitive disadvantage for Germany. Spain's export promotion empowers with a multiple of 40 and Italy's fuels with a multiple of 60 to the German funding [264]. Additionally, powerful measures from non-EU wine producing countries enhance their global sales [191], providing further explanation to German wines lagging in global trade growth.

The strategy surveys delivered two further insights regarding strategic export management. Firstly, providers with more intensive export (more countries served and export making up for more than $15 \%$ of their sales) showed above-average satisfaction with regards to winning new markets and profitability [265]. Secondly, a trade-off exists between export orientation and tourism-oriented offerings [266]. Growing market opportunities in other countries hence can serve to satisfy ambitious growth, but require adequate managerial efforts and investments; resource-scarce wineries need to address resource allocation in line with their strategic ambitions [267].

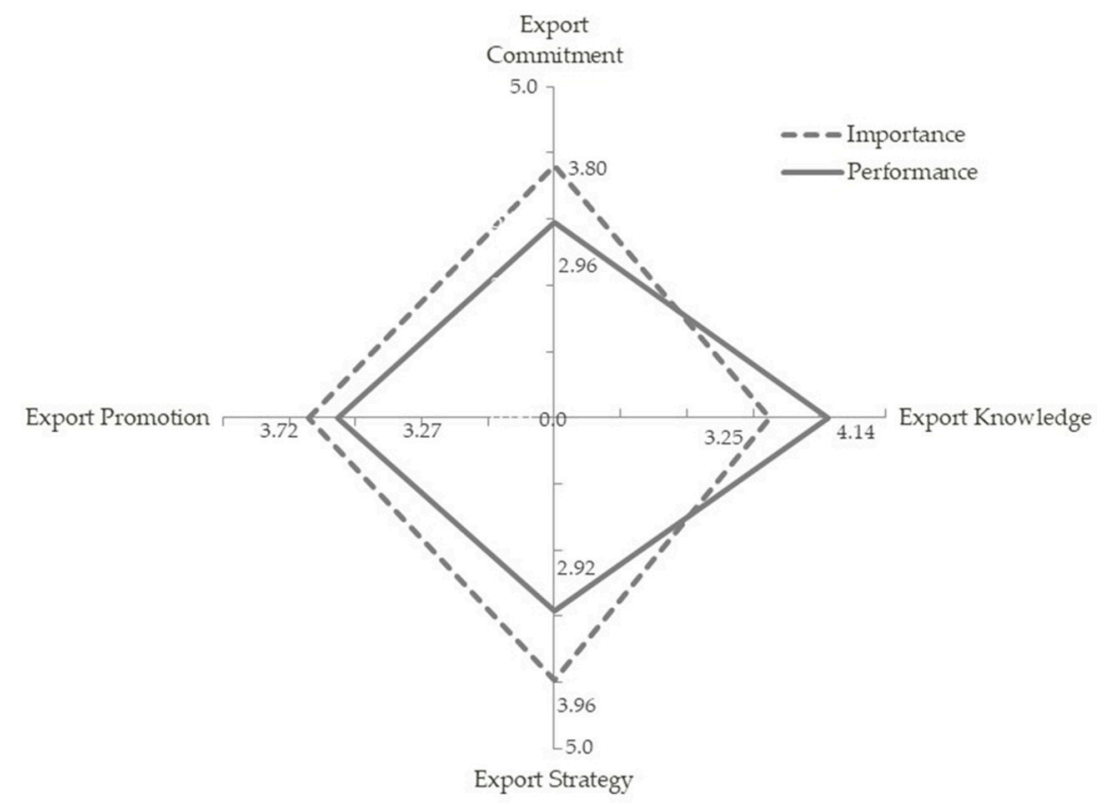

Figure 14. Key success factors in wine export and German performance (survey results).

\section{Discussion and Implications}

For strategic decisions, in-depth information on industries and markets is a prerequisite for success $[5,268]$. In order to facilitate strategic decision-making, the analysis followed the notion of strategic management processes $[3,5,13,269]$, shedding light on market data, trends, strategies, strategic grouping, clusters, and innovation management. A stable and voluminous wine consumption, combined with the curiosity of German consumers for home but also for foreign products, brings forth an attractive market size and a playground for diverse products and offers. Additionally, Germany developed as professional industrial platform to process international wines for global markets. The German wine market represents a very vivid market place. Given the low market entry barriers, it is highly competitive. Gathering the vast and various data on the German wine market complemented by the realized primary research, concludes that consumers in Germany spend more 
than 12 billion Euros annually on wine, including on-premise consumption, as well as sparkling wine. The economic value of wine exceeds pure production or wine sales. This market volume calculation deviates from often published and referenced market size figures $[87,224,270]$. On the basis of the realized research, the market volume of prior studies could be updated and invigorated [228], reflecting the consumer's willingness to pay for experience and to satisfy emotional needs. This market understanding motivates or reemphasizes the importance of the on-premise segments. Indeed, looking at the neighboring country of Austria, on-premise penetration with home grown products is of vital importance [271]. Such a perspective opens managerial opportunities for German wine and strategic win-win situations for wine suppliers and restaurants. Integrated innovative offerings, partnerships, forward integration of wineries, new paths for wine pricing, or creative wine sales strategies strongly relying on mutual relationships, are valid growth strategies for wineries and on-premise locations. Furthermore, an ample attractive market segment served by premium offers at higher prices exists to be won with innovative offers.

This industry study illustrates that despite an overall stable market (e.g., in consumption or vineyard surface), there are significant changes on the supply side and in consumer behavior. Cultural roots influenced consumption and production, but the demand for wine in Germany apparently shifts from traditional to modern values, impacting consumption, buying behavior, and supply. Suppliers need to acknowledge a changing environment, with increasing channel usage by the customers and curiosity for new offerings. As a result, customer brand loyalty is diminishing. The dynamism beyond the aggregated consumption or production volume of the German wine market calls for strategically-based decisions. Players need to decide whether they have ambition to serve the full market or target market niches. Strategic positioning is of paramount importance. Sustainable strategies with adequate organizational alignment to best prepare companies for the future need to consider the consumer changes, niche opportunities, competitors' moves, opportunities in export, tourism-based strategic prospects, and all other strategic alternatives to either grow, enter, or remain in the challenging market [11-14]. The research reveals that ambitious entrepreneurs are able to expand and leverage performance. Strategic positioning must be based on synchronized innovations. The historic and still prevailing focus on product quality needs to transition into creative, customer-centric offer design, as wine consumers feel limited in their capability to judge product quality [206-211]; an attractive offering, a winning story, and engaged communication, based on high product quality secures reputation to sustainably win and keep clients [214-217].

Given the predicted outlook of a market without growth, rivalry is expected to increase and structural change is forecasted to continue [228]. The paths of successful entrepreneurs in this industry indicate that growth is possible, but requires innovative ideas, ambition, and strategic approaches. Cost management must not be neglected and productivity gains in wine production in the past have been consumed by increasing marketing spending-a trend that will continue in the future. In light of the need for innovative offer design but parallel cost management, future research on the basis of the concept of "blue ocean strategies" [272], conquering new markets with adequate and fitting offer, seems appropriate. Certainly, the market welcomes entrepreneurial opportunities and therefore invites for additional research. The limitations of this paper, of being broad in approach and comprehensive in sources, asks for further complementary research. Future research is invited to realize an international comparison to help assess the optional potential market entries, besides Germany. Additionally, the German wine market is obviously in transition, asking for the constant revision of the market information.

Funding: Parts of the empirical research for this market review were supported by a research grant (FHprofUnt) financed by the German federal ministry for Education and Research. The author is thankful for the support.

Conflicts of Interest: The author declares no conflict of interest. 


\section{References}

1. Rückrich, K. Daten zur Weltweinwirtschaft. Der Deutsche Weinbau 2018, 10, 1.

2. OIV. World Vitiviniculture Situation 2016; OIV: Paris, France, 2016.

3. Porter, M.E. Competitive Strategy: Techniques for Analyzing Industries and Competitors; Free Press: New York, NY, USA, 1980.

4. Porter, M.E. What Is Strategy? Harvard Business Review; Harvard Business School Publishing: Boston, MA, USA, 1996; Volume 6, pp. 61-78.

5. Besanko, D.; Dranove, D.; Shanley, M.; Schaefer, S. Economics of Strategy; John Wiley \& Sons: Hobeken, NJ, USA, 2009.

6. Burns, T.; Stalker, G. Mechanistic and organic systems. In Classics of Organization Theory; Harcourt College Publishers: Fort Worth, TX, USA, 1961; pp. 201-205.

7. Chandler, A.D. Strategy and Structure: Chapters in the History of the Industrial Enterprise; MIT Press: Cambridge, MA, USA, 1990; Volume 120.

8. Hannan, M.T.; Freeman, J. Structural inertia and organizational change. Am. Sociol. Rev. 1984, 49, $149-164$. [CrossRef]

9. Hoffmann, F. Organisation-Umwelt-Beziehungen in der Organisationsforschung. Klassische und Neoklassische Organisationstheorien: Organisationstheoretische Ansätze, Munich; 1981; pp. 103-111.

10. DeSarbo, W.S.; Grewal, R.; Wind, J. Who competes with whom? A demand-based perspective for identifying and representing asymmetric competition. Strat. Manag. J. 2006, 27, 101-129. [CrossRef]

11. Miles, G.S.; Chales, C.; Sharfman, M.P. Industry variety and performance. Strat. Manag. J. 1993, 14, $163-177$. [CrossRef]

12. Miller, D. Configurations of strategy and structure: Towards a synthesis. Strat. Manag. J. 1986, 7, $233-249$. [CrossRef]

13. Porter, M.E. Competitive strategy, structure and firm performance. Harv. Bus. Rev. 1998, 76, 77-90. [PubMed]

14. Miller, D. The structural and environmental correlates of business strategy. Strat. Manag. J. 1987, 8, 55-76. [CrossRef]

15. Orth, U.R.; Lockshin, L.; d'Hauteville, F. The global wine business as a research field. Int. J. Wine Bus. Res. 2007, 19, 5-13. [CrossRef]

16. Ansoff, H.I. Corporate Strategy: An. Analytic Approach to Business Policy for Growth and Expansion; McGraw-Hill Companies: New York, NY, USA, 1965.

17. Fiegenbaum, A.; Thomas, H. Strategic groups and performance: The US insurance industry, 1970-1984. Strat. Manag. J. 1990, 11, 197-215. [CrossRef]

18. Pertusa-Ortega, E.M.; Molina-Azorín, J.F.; Claver-Cortés, E. Competitive strategy, structure; and firm performance. Manag. Decis. 2010, 48, 1282-1303. [CrossRef]

19. Porter, M.E. Towards a dynamic theory of strategy. Strat. Manag. J. 1991, 12, 95-117. [CrossRef]

20. Speed, R.J. Oh Mr Porter! A re-appraisal of competitive strategy. Mark. Intell. Plan. 1989, 7, 8-11. [CrossRef]

21. Houben, G.; Lenie, K.; Vanhoof, K. A knowledge-based SWOT-analysis system as an instrument for strategic planning in small and medium sized enterprises. Dec. Support Syst. 1999, 26, 125-135. [CrossRef]

22. Panagiotou, G. Bringing SWOT into focus. Bus. Strat. Rev. 2003, 14, 8-10. [CrossRef]

23. Grant, R.M. Contemporary Strategy Analysis: Text and Cases Edition; John Wiley \& Sons: Hobeken, NJ, USA, 2016.

24. Yinan, Q.; Xiande, Z.; Chwen, S. The Impact of Competitive Strategy and Supply Chain Strategy on Business Performance: The Role of Environmental Uncertainty. Dec. Sci. 2011, 42, 371-389.

25. Hunger, J.D.; Wheelen, T.L. Essentials of Strategic Management; Pearson: London, UK, 2014.

26. Wheelen, T.L.; Hunger, J.D. Concepts in Strategic Management and Business Policy; Pearson: London, UK, 2015.

27. Gupta, A. Environment \& PEST analysis: An approach to external business environment. Int. J. Mod. Soc. Sci. 2013, 2, 34-43.

28. Menet, G. The importance of strategic management in international business: Expansion of the PESTEL method. Int. Bus. Glob. Econ. 2016, 35, 261-270.

29. Clark, D.N. Strategic management tool usage: A comparative study. Strat. Chang. 1997, 6, 417-427. [CrossRef]

30. Tassabehji, R.; Isherwood, A. Management use of strategic tools for innovating during turbulent times. Strat. Chang. 2014, 23, 63-80. [CrossRef] 
31. Gilinsky, A.; Santini, C.; Lazzeretti, L.; Eyler, R. Desperately seeking serendipity. Int. J. Wine Bus. Res. 2008, 20, 302-320. [CrossRef]

32. Shamsuddoha, A.K.; Ali, M.Y. Mediated effects of export promotion programs on firm export performance. Asia Pac. J. Mark. Logist. 2006, 18, 93-110. [CrossRef]

33. Storchmann, K. Germany, Austria and Switzerland. In Wine Globalization; Cambridge University Press: Cambridge, UK, 2018; p. 92.

34. Gilles, K.-J.; König, M. Neuere Forschungen zum römischen Weinbau an Mosel und Rhein; Rheinisches Landesmuseum: Bonn, Germany, 1995.

35. Standage, T. A History of the World in 6 Glasses; Walker \& Co: New York, NY, USA, 2006.

36. Butzer, P.; Kerner, M.; Oberschelp, W. Charlemagne and his Heritage. 1200 Years of Civilization and Science in Europe; Brepols Publisher: Turnhout, Belgium, 1997.

37. Braun, K. Der Weinbau im Rheingau; Lüderitzsche Verlagshandlung: Berlin, Germany, 1869.

38. Phillips, R. Die große Geschichte des Weins; Campus-Verlag: Francfurt, Germany, 2001.

39. Trick, S. Der Deutsche Wein und die Globalisierung; Europäischer Hochschulverlag: Bremen, Germany, 2009; Volume Band 31.

40. Frank, B. Die Diffusion von Rebsorten-Eine globale Betrachtung; Markgraf Publishers: Weikersheim, Germany, 2010; Volume 97.

41. Umweltbundesamt. Struktur der Flächennutzung; Umweltbundesamt: Dessau-Roßlau, Germany, 2018.

42. Wirtschaftlicher Vereinigung Zucker. Süßes aus der Erde; Wiesbadener Kurier, VRM: Mainz, Germany, 2017.

43. BMELV. Land-, Forst- und Ernährungswirtschaft mit Fischerei und Wein- und Gartenbau; BMELV: Bonn, Germany, 2017.

44. DBV. Situationsbericht 2011/12 —Trends und Fakten zur Landwirtschaft; DBV: Berlin, Germany, 2012.

45. DeStatis. Bruttoinlandsprodukt 2016 für Deutschland; DeStatis: Wiesbaden, Germany, 2017.

46. Hensche, H.; Lorleberg, W. Volkswirtschaftliche Neubewertung des Gesamten Agrarsektors und Seiner Netzwerkstrukturen; Forschungsberichte des Fachbereichs Agrarwirtschaft: Soest, Germany, 2011.

47. Brunner, K.-M. Essen, Trinken und Reisen im gesellschaftlichen Wandel - Potenziale für Weintourismus aus (wein-)soziologischer Perspektive. In Wein und Tourismus; Dreyer, A., Ed.; Erich Schmidt Verlag: München, Germany, 2011; Volume 11, pp. 37-47.

48. Bundesbank, D. Deutschlands Reisebilanz. Wiesbadener Kurier, 30 June 2017.

49. Faugère, C.; Bouzdine-Chameeva, T.; Durrieu, F.; Pesme, J.-O. The impact of tourism strategies and regional factors on wine tourism performance. In Proceedings of the 7th International Conference AWBR, St. Catherines, ON, Canada, 12-15 June 2013.

50. Koch, J.; Martin, A.; Nash, R. Overview of perceptions of German wine tourism from the winery perspective. Int. J. Wine Bus. Res. 2013, 25, 50-74. [CrossRef]

51. Orth, U.S.; Stöckl, A. Wein \& Tourismus: Determinanten und Konsequenzen emotionaler Bindung zu Regionen und deren Marken. In Wein und Tourismus; Dreyer, A., Ed.; Erich Schmidt Verlag: Munich, Germany, 2011; Volume 11, pp. 49-60.

52. Dreyer, A. Wein und Tourismus_Erfolg durch Synergien und Kooperationen; Erich Schmidt Verlag: Munich, Germany, 2011; Volume 11.

53. Chang, S. Experience economy in hospitality and tourism: Gain and loss values for service and experience. Tour. Manag. 2018, 64, 55-63. [CrossRef]

54. Bundesamt, S. Erste offizielle Ernteschätzung. In Weinwirtschaft; Meininger Verlag: Neustadt, Germany, 2018.

55. DWI. Deutscher Wein Statistik 2017/2018; DWI: Mainz, Germany, 2018; pp. 1-40.

56. Statista. Produktionsmenge von Wein. 2017. Available online: Statista.com/statistik/daten/studie (accessed on 20 November 2018).

57. Loose, S.; Pabst, E. Current State of the German and International Wine Markets. Oceania 2018, 634, 1-9.

58. Bogonos, M.; Engler, B.; Oberhofer, J.; Dressler, M.; Dabbert, S. Planting Rights Liberalization in the European Union: An Analysis of the Possible Effects on the Wine Sector in Rheinland-Pfalz, Germany. Ger. J. Agric. Econ. 2016, 65, 30-40.

59. Deconinck, K.; Swinnen, J. The Economics of Planting Rights. LICOS Centre for Institutions and Economic Performance Discussion. 2013. Available online: https://ideas.repec.org/s/lic/licosd.html (accessed on 20 November 2018). 
60. Dpa. Mehr Weinanbau in Deutschland Möglich: Bundestag für mehr Fläche; Rhein Zeitung: Koblenz, Germany, 2015.

61. Deutscher Bundestag. Drucksache 18/4656. V. 20.4.2015, Köln, Bundesanzeiger: 2015. Available online: http:/ / dip21.bundestag.de/dip21/btd/18/046/1804656.pdf (accessed on 20 November 2018).

62. Bindi, M.; Howden, M. Challenges and Opportunities for Cropping Systems in a Changing Climate. In Proceedings of the 4th International Crop Science Congress, Brisbane, Australia, 26 September-1 October 2004.

63. DeGaetano, A.T.; Belcher, B.N. Spatial interpolation of daily maximum and minimum air temperature based on meteorological model analyses and independent observations. J. Appl. Meteorol. Climatol. 2007, 46, 1981-1992. [CrossRef]

64. Hera, U.; Rötzer, T.; Zimmermann, L.; Schulz, C.; Maier, H.; Weber, H.; Kölling, C. Klima en détail. LWF aktuell 2012, 86, 34-37.

65. Huglin, P. Nouveau mode d'évaluation des possibilités héliothermiques d'un milieu viticole. Comptes rendus des séances 1978. Available online: http:/ / agris.fao.org/agris-search/search.do?recordID=US201301392531 (accessed on 20 November 2018).

66. Johnson, G.L.; Daly, C.; Taylor, G.H.; Hanson, C.L. Spatial variability and interpolation of stochastic weather simulation model parameters. J. Appl. Meteorol. 2000, 39, 778-796. [CrossRef]

67. Kovács, L.G.; Byers, P.L.; Kaps, M.L.; Saenz, J. Dormancy, cold hardiness, and spring frost hazard in Vitis amurensis hybrids under continental climatic conditions. Am. J. Enol. Viticul. 2003, 54, 8-14.

68. Molitor, D.; Caffarra, A.; Sinigoj, P.; Pertot, I.; Hoffmann, L.; Junk, J. Late frost damage risk for viticulture under future climate conditions: A case study for the Luxembourgish winegrowing region. Aust. J. Grape Wine Res. 2014, 20, 160-168. [CrossRef]

69. Statistisches Bundesamt. Bestockte Rebfläche 2005-2017; DWV: Bonn, Germany, 2018.

70. Eurostat. 2017. Available online: https://ec.europa.eu/eurostat/statistics-explained/index.php/Vineyards_ in_the_EU_-_statistics (accessed on 20 November 2018).

71. Rückrich, K. Stand der Rebsortenzulassung. Der Deutsche Weinbau 2018, 16/17, 1.

72. GfK. Weinmarkt Deutschland_Verbraucher-Analysen Jahr 2016; GfK: Nuremberg, Germany, 2017; not published.

73. DWI. Öko-Weinbau in Deutschland Immer Beliebter; DWI: Mainz, Germany, 2018.

74. Umweltbundesamt. Umwelt und Landwirtschaft 2018; Umweltbundesamt: Dessau, Germany, 2018.

75. Cohen, E.; Goodman, S.; Remaud, H.; Lockshin, L. Building brand salience for commodity-based wine regions. Int. J. Wine Bus. Res. 2009, 21, 79-92.

76. Thomas, L.C.; Painbéni, S.; Barton, H. Entrepreneurial marketing within the French wine industry. Int. J. Entrep. Behav. Res. 2013, 19, 238-260. [CrossRef]

77. Van Leeuwen, C.; Seguin, G. The concept of terroir in viticulture. J. Wine Res. 2006, 17, 1-10. [CrossRef]

78. RLP. Weinbau-bestockte Rebfläche; Statistisches Landesamt Rheinland-Pfalz: Mainz, Germany, 2010.

79. BMELV. Ertragslage Obst-und Weinbau 2016; Abt, R., Ed.; BMELV: Bonn, Germany, 2016; pp. 92-131.

80. Sellers-Rubio, R. Evaluating the economic performance of Spanish wineries. Int. J. Wine Bus. Res. 2010, 22, 73-84. [CrossRef]

81. Mend, M. Wie steht's mit dem Erfolg? Das Deutsche Weinmagazin 2009, 12/13, 26-28.

82. Oberhofer, J. Agrarbericht 2012: Erfreuliche Entwicklung an der Mosel. Der Deutsche Weinbau 2013, 16, 14-19.

83. Oberhofer, J. Agrarbericht—Erfreuliche Entwicklung. Der Deutsche Weinbau 2018, 16, 16-22.

84. BMELV. Ertragslage Obst-und Weinbau 2012; BMELV: Bonn, Germany, 2012; pp. 90-123.

85. SBA. Agrarstrukturerhebung 2010; Statistisches Bundesamt: Wiesbaden, Germany, 2011.

86. BMELV. Ertragslage Obst-und Weinbau 2011; Abt, R., Ed.; BMELV: Bonn, Germany, 2011; pp. 86-119.

87. DWI. Deutscher Wein Statistik 2016/2017; DWI: Mainz, Germany, 2017; pp. 1-40.

88. Scheuermann, M. Die 50 größten Weingüter. In Drunkenmonday; 2012; Volume 2018. Available online: https: / / drunkenmonday.wordpress.com/2010/11/17/die-50-grosten-weinguter (accessed on 20 November 2018).

89. Lambeck, M. Deutschlands größtes Weingut. Bild-Zeitung. Available online: www.bild.de/lifestyle/essentrinken/edle-alkohole-weine/weinkolumne-kloster-eberbach-33914410 (accessed on 20 November 2018).

90. Mieding, N. Der Dino unter den Winzern. Rheinzeitung, 12 March 2016.

91. Atkin, T.; Gilinsky, A.; Newton, S.K. Sustainability in the Wine Industry: Altering the Competitive Landscape? In Proceedings of the 6th AWBR International Conference, Bordeaux, France, 9-10 June 2011. 
92. Algner, M.; Fritsch, A.; Reichel, R. Winzergenossenschaften im Wettbewerb. ZfgG 2007, 57, $167-177$. [CrossRef]

93. DRV. Deutsche Winzergenossenschaften. Available online: https://www.raiffeisen.de/wein (accessed on 20 November 2018).

94. Grosskopf, W.M.; Hans, H.; Ringle, G. Unsere Genossenschaften-Idee, Auftrag, Leistungen; Deutscher Genossenschaftsverlag: Wiesbaden, Germany, 2009.

95. DRV. Weinwirtschaftsjahr-Auszüge; Deutscher Raiffeisenverband: Berlin, Germany, 2012.

96. Dpa. “Jeder macht, was er kann”-Wenn Winzer sich zusammenschließen. Merkur.de. Available online: www. merkur.de/wirtschaft/wenn-winzer-sich-zusammenschliessen-zr-10219953 (accessed on 20 November 2018).

97. Anonymous. Moselland eG feiert "50 Jahre eine starke Gemeinschaft" Eifel Zeitung. Available online: www.eifelzeitung.de/region/bernkastel-wittlich/moselland-eg-feiert-50-jahre-eine-starke-gemeinschaft177438 (accessed on 20 November 2018).

98. Gerke, C. Rückkehr an die Spitze. Weinwirtschaft 2018, 4, 146-152.

99. Kolb, S. Winzergenossenschaften auf dem Weg in die Zukunft; Deutscher Raiffeisenverband: FES, Kirrweiler, 2012.

100. Gerke, C. Größe gesucht. Weinwirtschaft 2012, 4, 122-125.

101. BVW. Wer Sind Wir und Was Tun Wir? Available online: www.ihk-trier.de (accessed on 20 November 2018).

102. Pilz, H. Es rauscht im Karton. Weinwirtschaft 2018, 4, 142-146.

103. Schallenberger, F. Weinbau. Made in Germany. Der deutsche Weinmarkt im Blickfeld; LBBW: Mainz, Germany, 2009; pp. 1-36.

104. Fiegenbaum, A.; Thomas, H. Strategic groups as reference groups: Theory, modeling and empirical examination of industry and competitive strategy. Strat. Manag. J. 1995, 16, 461-476. [CrossRef]

105. Fiegenbaum, A. Strategic Groups and Performance: The US Insurance Industry; University of Michigan, School of Business Administration: Ann Arbor, MI, USA, 1987.

106. Ward, P.T.B.; Deborah, J.; Leong, G.K. Configurations of manufacturing strategy, business strategy, environment and structure. J. Manag. 1996, 22, 597-626. [CrossRef]

107. Ward, P.T.D. Rebecca, Manufacturing strategy in context: Environment, competitive strategy and manufacturing strategy. J. Oper. Manag. 2000, 18, 123-138. [CrossRef]

108. Porter, M.E. Competitive Advantage: Creating and Sustaining Superior Performance; Free Press: New York, NY, USA, 1985.

109. Porter, M.E. From competitive advantage to corporate strategy. McKinsey Q. 1988, 2, 35-66.

110. Porter, M.E. What is strategy? In Strategy for business: A Reader; Mazzucato, M., Ed.; Sage: New York, NY, USA, 2002.

111. Campbell-Hunt, C. What have we learned about generic competitive strategy? A meta-analysis. Strat. Manag. J. 2000, 21, 127-154. [CrossRef]

112. Porter, M.E. Location, Competition, and Economic Development: Local Clusters in a Global Economy. Econ. Dev. Q. 2000, 14, 15-34. [CrossRef]

113. Dressler, M. Strategic grouping in a fragmented market: SMEs' strive for legitimacy. Int. J. Entrep. Small Bus. 2017, 32, 229-253. [CrossRef]

114. Santini, C.; Cavicchi, A.; Gilinsky, A.; Newton, S.; Rabino, S. Niche Strategy and Resources: Dilemmas and open questions, an exploratory study. In Proceedings of the 8th International Conference, Academy of Wine Business Research, Geisenheim, Germany, 28-30 June 2014.

115. Freter, H. Markt-und Kundensegmentierung, 2nd ed.; Kohlhammer: Stuttgart, Germany, 2008.

116. Touzard, J.-M. Innovation Systems and Regional Vineyards. ISDA: Montpellier, France, 2010; pp. 1-13.

117. Gray, A.; Boehlje, M.; Amanor-Boadu, V.; Fulton, J. Agricultural innovation and new ventures: Assessing the commercial potential. Am. J. Agric. Econ. 2004, 86, 1322-1329. [CrossRef]

118. Kumar, N. Marketing as Strategy; HBS Press: Boston, MA, USA, 2004.

119. Kotler, P. The Prosumer Movement: A new challenge for marketers. Adv. Consum. Res. 1986, 13, 510-513.

120. Bloemer, J.; Ruyter, K.D. Customer Loyalty in High and Low Involvement Service Settings: The Moderating Impact of Positive Emotions. J. Mark. Manag. 1999, 15, 315-330. [CrossRef]

121. Carù, A.; Cova, B. Revisiting Consumption Experience a More Humble but Complete View of the Concept. Mark. Theory 2003, 3, 267-286. [CrossRef]

122. Ravald, A.G.; Grönroos, C. The value concept and relationship marketing. Eur. J. Mark. 1996, 30, 19-30. [CrossRef] 
123. Dess, G.G.; Davis, P.S. Porter's (1980) Generic Strategies as Determinants of Strategic Group Membership and Organizational Performance. Acad. Manag. J. 1984, 27, 467-488.

124. Göbel, R. Marketingstrategische Ausrichtung und Veränderungsfähigkeit als Ursache des wirtschaftlichen Erfolges analysiert am Beispiel direktvermarktender Weingüter. Geisenheimer Berichte 2003, 49, 1-163.

125. BÖLN. Höhere Preise fördern die Nachfrage. Das Deutsche Weinmagazin, 2 July 2018.

126. Dressler, M. Ökologischer Weinbau: Positionierungsanalysen. Der Deutsche Weinbau 2013, 5, 16-18.

127. Siebold, H. Ökoweingut Findet Einen Potenten Retter. Available online: www.stuttgarter-zeitung.de/inhalt. kaiserstuhl-oekoweingut-findet-einen-potenten-retter.489584de-5f25-4a1f-8c88-b5600556fff7.html (accessed on 20 Novermber 2018).

128. Dressler, M. Umweltadaption durch Innovation-Strategische Maßnahmen bei Umweltveränderungen am Beispiel Weinbau. zfO 2018, 87, 24-32.

129. Zahra, S.A.; George, G. Absorptive capacity: A review, reconceptualization, and extension. Acad. Manag. Rev. 2002, 27, 185-203. [CrossRef]

130. Hamilton, B.H.; Nickerson, J.A. Correcting for endogeneity in strategic management research. Strat. Organ. 2003, 1, 51-78. [CrossRef]

131. BCG. Organisation 2015-Designed to Win; The Boston Consulting Group: Boston, MA, USA, 2009.

132. Schwiddessen, J. Da muss man schon was tun. Wiesbadener Kurier, 13 October 2018.

133. Dressler, M. Vertriebsmanagement-Multikanaler und moderner Vertrieb. In Deutsches Weinbaujahrbuch 2016; Schultz, H.-R., Stoll, M., Eds.; Ulmer: Stuttgart, Germany, 2016; Volume 67, pp. 69-77.

134. Malheiro, A.C.; Santos, J.A.; Pinto, J.G.; Jones, G.V. European Viticulture Geography in a changing climate. OIV Bull. 2012, 85, 15-22.

135. Nielsen. Handel, Verbraucher, Werbung-Deutschland 2011; The Nielsen Company: New York, NY, USA, 2012.

136. DWI. Deutscher Wein Statistik 2012/2013; DWI: Mainz, Germany, 2012; pp. 1-36.

137. Ipsos. Europäer und Biowein. Available online: http://www.marktmeinungmensch.de/studien/ipsosstudie-weinkonsum-und-bio-wein-in-deutschland (accessed on 20 November 2018).

138. Pabst, A.; Kraus, L.; Matos, E.G.D.; Piontek, D. Substanzkonsum und substanzbezogene Störungen in Deutschland im Jahr 2012. Sucht 2013, 59, 321-331. [CrossRef]

139. Aizenman, J.; Brooks, E. Globalization and Taste Convergence: The Cases of Wine and Beer. Rev. Int. Econ. 2008, 16, 217-233. [CrossRef]

140. MDS. VerbraucherAnalyse. Available online: www.verbraucheranalyse.de/fakten/studie (accessed on 20 November 2018).

141. OIV. World Vitiviniculture Situation 2012; OIV: Paris, France, 2012.

142. Markgraf, H. Die Deutschen lieben Sekt. 2012. AHGZ. Available online: https://www.ahgz.de/zulieferer/ die-deutschen-lieben-sekt (accessed on 20 November 2018).

143. Anderson, K.; Nelgen, S. Global Wine Markets 1961-2009: A Statistical Compendium; University of Adelaide Press: Adelaide, Australia, 2011.

144. OIV. World Vitiviniculture Situation 2013; OIV: Paris, France, 2013.

145. Wiesgen-Pick, A. Daten aus der Alkoholwirtschaft 2016; Bundesverband der Deutschen Spirituosen-Industrie und -Importeure e. V. (BSI): Bonn, Germany, 2016.

146. WHO. Alkoholkonsum in Europa; Dpa, Ed.; Verlagsgruppe Rhein-Main: Wiesbadener Kurier, Germany, 2018; p. 8.

147. Statista. Pro-Kopf-Verbrauch von Bier, Wein, Schaumwein und Spirituosen in Deutschland. Available online: Statista.com/statistik/daten/studie (accessed on 20 November 2018).

148. Handelsblatt, Markt für Spirituosen-Werbeausgaben der Branche. Grafik, H., Ed. HB. Available online: https:/ / www.handelsblatt.com/infografiken/grafik/ (accessed on 20 September 2018).

149. Nielsen. Entwicklung der Werbeausgaben für Wein 2000-2017; Statista: Hamburg, Germany, 2018.

150. Nielsen. Consumers Deutschland; Nielsen: Hamburg, Germany, 2017.

151. Haupt, D. Weinwirtschaftsbericht; MWVLW Rheinland Pfalz: Mainz, Germany, 2010.

152. DWI. Deutscher Wein Statistik 2010/2011; DWI: Mainz, Germany, 2011; pp. 1-36.

153. Szolnoki, G.; Hoffmann, D. Neue Weinkunden-Segmentierung in Deutschland. In Proceedings of the 37th World Congress of Vine and Wine and 12th General Assembly of the OIV, EDP Sciences, Mendoze, Argentina, 9-14 November 2014; p. 07002. 
154. Szolnoki, G.; Hoffman, D. Neue Weinkundensegmentierung in Deutschland; Hochschule Geisenheim: Geisenheim, Germany, 2014; Volume 73.

155. Mannheim, U.O. Studie zum Konsum von Wein. Available online: www.natuerlichkork.de (accessed on 20 November 2018).

156. Nielsen. Deutsche geben Milliarden für alkoholische Getränke aus. Available online: https://www. proplanta.de/Agrar-Nachrichten/Verbraucher:Düsseldorf (accessed on 20 November 2018).

157. Research, S. Weinatlas Deutschland; Splendid Research: Hamburg, Germany, 2018.

158. Hoffmann, D.; Szolnoki, G. Der Premiummarkt für Weine in Deutschland; MULEWF Rheinland Pfalz: Mainz, Germany, 2011; pp. 1-83.

159. Haupt, D. Weissweinstudie—Repräsentative Verbraucheruntersuchung; MWVLW Rheinland Pfalz: Mainz, Germany, 2006; pp. 1-120.

160. GfK. Verbraucher-Analysen Wein 2017; Gesellschaft für Konsumforschung: Nuremberg, Germany, 2018.

161. Hoffmann, D. Stabiler Markt. Weinwirtschaft 2010, 5, 167-168.

162. Dressler, M. Reputationsmanagement und Einfluss auf die Preisdurchsetzung-Empirische Einsichten. In Deutsches Weinbaujahrbuch 2017; Schultz, H.-R., Stoll, M., Eds.; Ulmer: Stuttgart, Germany, 2017; Volume 68, pp. $118-124$.

163. Fleuchaus, R.; Arnold, R.C. Weinmarketing: Kundenwïnsche Erforschen, Zielgruppen Identifizieren, Innovative Produkte Entwickeln; Gabler Verlag: Wiesbaden, Germany, 2010.

164. Dressler, M. Strategic winery reputation management-Exploring German wine guides. Int. J. Wine Bus. Res. 2016, 28, 4-21. [CrossRef]

165. DWI. Deutsche Weine aus Sicht der Konsumenten; DWI: Mainz, Germany, 2013.

166. Riviezzo, A.; De Nisco, A.; Garofano, A. Understanding wine purchase and consumption behaviour: A market segmentation approach. In Proceedings of the 6th AWBR International Conference, Bordeaux, Germany, 9-10 June 2011.

167. Arnold, R.; Fleuchaus, R. Ein Überblick zu Segmentierungsansätzen im Weinmarketing. In Weinmarketing: Kundenwünsche Erforschen, Zielgruppen Identifizieren, Innovative Produkte Entwickeln; Fleuchaus, R.A., Ed.; Gabler Verlag: Wiesbaden, Germany, 2010; pp. 119-144.

168. Olsen, J.; Newton, S.K. Millenial Wine Consumer Dining Preferences Segmented by Restaurant TypeAn Exloratory Study. In Proceedings of the 6th AWBR International Conference, Bordeaux, Germany, 9-10 June 2011; pp. 1-12.

169. Corsi, A.M.; Lockshin, L.; Mueller, S. Competition between and competition within: The strategic positioning of competing countries in key export markets. In Proceedings of the 6th International Conference, AWBR, Bordeaux, France, 9-10 June 2011.

170. Reule, M. Zielgruppen für deutsche Weine 2013; Weinmarkt, A.T.I.D., Ed.; DWI: Dresden, Germany, 2014.

171. Sociodimensions. Deutsche Weine aus Sicht der Konsumenten; DWI: Mainz, Germany, 2013.

172. Schipperges, M. Verbraucher offen für neue Entdeckungen. Das deutsche Weinmagazin 2013, 17/18, 58-63.

173. DWI. Die Wahrnehmung deutscher Weine aus Sicht der Konsumenten. Available online: https: / /www.lwg.bayern.de/mam/cms06/weinbau/dateien/14_wbt_20140220-fränkische-weinwirtschaftstageimage-zielgruppen.pdf (accessed on 20 November 2018).

174. Wiesgen-Pick, A. Pro-Kopf-Verbrauch der verschiedenen alkoholhaltigen Getränke nach Bundesländern 2015; Bundesverband der Deutschen Spirituosen-Industrie und -Importeure e. V. (BSI): Bonn, Germany, 2016.

175. Dünnebacke, T. Steigende Lust auf deutsche Weine. Lebensmittelpraxis. Available online: https:// lebensmittelpraxis.de/sortiment/11401-wein-und-sekt-steigende-lust-auf-deutsche-weine (accessed on 20 November 2018).

176. Nestlé. So is(s)t Deutschland—Ein Spiegel der Gesellschaft; Nestlé Deutschland AG: Frankfurt Main, Germany, 2011.

177. Nielsen. Deutsche gehen seltener einkaufen dpa, Ed. Available online: stuttgarter-nachrichten.de (accessed on 20 November 2018).

178. Haucap, J.; Heimeshoff, U.; Klein, G.J.; Rickert, D.; Wey, C. Wettbewerbsprobleme im Lebensmitteleinzelhandel; Düsseldorfer Institut für Wettbewerbsökonomie: Düsseldorf, Germany, 2013.

179. Cohen, E.; D'Hauteville, F.; Goodwill, S.; Lockshin, L.; Sirieix, L. A cross-cultural comparison of choice criteria for wine in restaurants. In Proceedings of the 4th International Conference of AWBR, Siena, Italy, 17-19 July 2008; pp. 1-18. 
180. Statista. Umsatz mit Wein in Deutschland nach Vertriebsformen in den Jahren 2008 bis 2014 (in Mrd. Euro). 2015. Available online: Statista.com/statistik/daten/studie (accessed on 20 November 2018).

181. Engelhard, W. Konsumhype geht an Wein vorbei. Markt+Wein 2017, 3, 78-82.

182. Rabobank. The Incredible Bulk; Rabobank: Utrecht, The Netherlands, 2012.

183. Engelhard, W. Harddiscounter: Verloren Und Trotzdem Gewonnen. Wein+Markt 2011, 16-17.

184. Engelhard, W. Wieder weniger Weinkunden. Wein+Markt 2011, 14-15.

185. Engelhard, W. Erneuter Absatzknick. Wein+Markt 2011, 18-19.

186. Engelhard, W. Rückschlag. Markt+Wein 2017, 3, 72-75.

187. Engelhard, W. Ernüchterung. Markt+Wein 2017, 3, 76-77.

188. DWI. Trend zum Weinkauf in Supermärkten hält an. Available online: https://www.deutscheweine.de/ presse/pressemeldungen/details/news/detail/News/trend-zum-weinkauf-in-supermaerkten-haelt-an/ (accessed on 20 November 2018).

189. OC\&C. Erwartete Konsumentenreaktion auf Preiserhöhung je Land. 2011/2012; OC\&C Strategy Consultants: Hamburg, Germany, 2012.

190. OC\&C. Messers Schneide-Die Preisstrategie als wesentlicher Erfolg des Geschäftsmodells; OC\&C Strategy Consultants: Hamburg, Germany, 2013.

191. COGEA. Study on the Competitiveness of European Wines; European Commission: Luxembourg, 2014; pp. 1-146.

192. Hoffmann, D.; Szolnoki, G. Consumer segmentation based on usage of sales channels in the German wine market. Int. J. Wine Bus. Res. 2014, 26, 27-44.

193. Ghvanidze, S.T.L.; Fleuchaus, R. Die Bedeutung des Wein Herkunftslandes für die Wahrnehmung der Konsumenten-Eine Kausalanalyse. IL Jahrestagung: Oppenheim, Germany, 2011; pp. 73-76.

194. Szolnoki, G.; Heußler, N.; Bleich, S. Analysis of prices and geografical origins as quality indicators. Le Bulletin de l'OIV 2009, 82, 411-420.

195. Hall, C.M.M.R. Wine Marketing; Butterworth-Heinemann: Oxford, UK, 2010.

196. Kern, M.; Müller, S. Sensorische Konsumentenforschung für modernes Weinmarketing. Weinmarketing: Kundenwünsche erforschen, Zielgruppen identifizieren, innovative Produkte entwickeln; Fleuchaus, R., Arnold, R., Eds.; Gabler Verlag: Wiesbaden, Germany, 2010; pp. 75-118.

197. Orth, U. Weinkonsumentenverhalten—Der aktuelle Stand der Forschung und Ausblick. In Weinmarketing; Fleuchaus, R., Arnold, R., Eds.; Gabler Verlag: Wiesbaden, Germany, 2010; pp. 5-33.

198. Castriota, S.; Curzi, D.; Delmastro, M. Tasters' Bias in Wine Guides' Quality Evaluations. Appl. Econ. Lett. 2013, 20, 1174-1177. [CrossRef]

199. Gokcekus, O.; Nottebaum, D. The Buyer's Dilemma-Whose Rating Should a Wine Drinker Pay Attention to? Am. Assoc. Wine Econ. Work. Pap. 2011, 91, 1-12.

200. Karpik, L. Valuing the Unique: The Economics of Singularities; Princeton University Press: Princeton, NJ, USA, 2010.

201. Akerlof, G.A. The Market for "Lemons": Quality Uncertainty and the Market Mechanisms. Q. J. Econ. 1970, 84, 488-500. [CrossRef]

202. Bagwell, K.; Riordan, M.H. High and Declining Prices Signal Product Quality. Am. Econ. Rev. 1991, 81, 224-239.

203. Castriota, S.; Delmastro, M. The economics of collective reputation: Minimum quality standards, vertical differentiation and optimal group size. AAWE 2009. working paper 50.

204. Andersson, F. Pooling Reputation. Int. J. Ind. Organ. 2002, 20, 715-730. [CrossRef]

205. Ling, B.-H.; Lockshin, L. Components of wine prices for Australian wine: How winery reputation, wine quality, region, vintage, and winery size contribute to the price of varietal wines. Australas. Mark. J. (AMJ) 2003, 11, 19-32. [CrossRef]

206. Lachmann, U.; Arnold, R. Wie funktioniert Weinkommunikation? ... Und wie nicht? Weinmarketing: Kundenwïnsche Erforschen, Zielgruppen Identifizieren, Innovative Produkte Entwickeln; Fleuchaus, R., Arnold, R., Eds.; Gabler Verlag: München, Germany, 2011.

207. Schneider, C. Präferenzbildung bei Qualitätsunsicherheit: Das Beispiel Wein; Duncker\&Humblodt: Schriften zum Marketing, Berlin, Germany, 1997.

208. Häusel, H.G. Brain View: Warum Kunden Kaufen; Rudolf Haufe Verlag: München, Germany, 2008.

209. Ashenfelter, O. Predicting the Quality and Prices of Bordeaux Wine. Econ. J. 2008, 118, 174-184. [CrossRef] 
210. Gergaud, O.; Livat, F. How Do Customers Use Signals to Assess Quality? Am. Assoc. Wine Econ. Work. Pap. 2007, 3, 1-22.

211. Schiefer, J.; Fischer, C. The Gap between Wine Experts Ratings and Consumer Preferences: Measures, Determinants and Marketing Implictaions. Int. J. Wine Bus. Res. 2008, 20, 335-351. [CrossRef]

212. Charters, S.; Pettigrew, S. Is Wine Consumption an Aesthetic Experience? J. Wine Res. 2005, 16, $121-136$. [CrossRef]

213. Olsen, J.; Newton, S.K. Millenial Wine Consumer Dining Preferences Segmented by Restaurant Type. In Proceedings of the 6th International Conference, AWBR, Bordeaux, France, 9-10 June 2011.

214. Winfree, J.A.; McCluskey, J.J. Collective Reputation and Quality. Am. J. Agric. Econ. 2005, 87, $206-213$. [CrossRef]

215. Kirmani, A.; Rao, A.R. No pain, no gain: A critical review of the literature on signaling unobservable product quality. J. Mark. 2000, 64, 66-79. [CrossRef]

216. Landon, S.; Smith, C.E. Quality expectations, reputation, and price. South. Econ. J. 1998, 64, $628-647$. [CrossRef]

217. Shapiro, C. Premiums for high quality products as returns to reputations. Q. J. Econ. 1983, 659-679. [CrossRef]

218. Cavusgil, S.T.; Hult, G.T.M.; Kiyak, T.; Deligonul, S.; Lagerström, K. What Drives Performance in Globally Focused Marketing Organizations? A Three-Country Study. J. Int. Mark. 2007, 15, 58-85.

219. Castriota, S.; Delmastro, M. Individual and Collective Reputation: Lessons from the Wine Market. L'industria 2010, 31, 149-172. [CrossRef]

220. Schrader, C. Reputation und Kaufverhalten: Eine empirische Analyse am Beispiel der Vermarktung deutscher Weine in Großbritannien; Universität Hamburg: Hamburg, Germany, 2008.

221. Benfratello, L.; Piacenza, M.; Sacchetto, S. Taste or reputation: What drives market prices in the wine industry? Appl. Econ. 2009, 41, 2197-2209. [CrossRef]

222. Jung, C.H.D. Strategic groups in Spezialized Wine Retail in Germany. In Proceedings of the 6th International Conference of the Association of Wine Business Research, Bordeaux, France, 9-10 June 2011.

223. DWI. Weineinkauf privater Haushalte in Deutschland im Handel-4. Quartal 2013; DWI: Mainz, Germany, 2014; pp. 1-36.

224. DWI. Deutscher Wein Statistik 2015/2016; DWI: Mainz, Germany, 2015; pp. 1-39.

225. Pekel. Tourismus: Gäste und Übernachtungen im Reiseverkehrm, Beherbergungskapazität_Vorläufige Ergebnisse; Statistisches Landesamt Sachsen-Anhalt: Halle, Germany, 2013.

226. Dressler, M. Innovative Weinwelt: Der “aktive Kunde". Der Deutsche Weinbau 2012, 6, 16-18.

227. DWI. Weinmarkt 2010; DWI: Mainz, Germany, 2011.

228. MarketLine. Wine Industry Profile: Germany; MarketLine: London, UK, 2012; pp. 1-32.

229. Dressler, M. Innovation focus and capacity challenge of small entrepreneurs-Looking at German wineries. In Proceedings of the International Conference on Innovation \& Trend in Wine Management, Dijon, France, 22 June 2012.

230. Ernest-Hahn, S. Wein in der Gastronomie; Matthaes: Stuttgart, Germany, 2005.

231. Dressler, M. Perfekter Absatz-Kunden und struktureller Wandel fordern professionellen Vertrieb. Das Deutsche Weinmagazin 2015, 20, 17-19.

232. Hoffmann, D. Der deutsche Weinmarkt 2009. Das Deutsche Weinmagazin 2010, 5/6, 56-58.

233. Heilig, A.T.B.; Tschernavskij, A. Studie zeigt großes Potential im Online-Handel! Das deutsche Weinmagazin 2012, 15, 24-27.

234. Nitt-Drießelmann, D. Einzelhandel im Wandel; Hamburgisches Weltwirtschafts Institut: Hamburg, Germany, 2013.

235. GfK. Weinmarkt Deutschland_Verbraucher-Analysen Jahr 2015; Gesellschaft für Konsumforschung: Nuremberg, Germany, 2016; in press.

236. GfK. Online-Weinkäufer legen Wert auf Qualität; Gesellschaft für Konsumforschung: Nuremberg, Germany, 2015; in press.

237. Pilz, H. Ungewisse Zukunft. Weinwirtschaft 2018, 21, 26-29.

238. Mangelsdorf, F. Rotkäppchen-Mumm legt weiter zu und investiert. Märkische Oberzeitung, 28 October 2012.

239. GfK. Weinmarkt Deutschland_Verbraucher-Analysen Jahr 2014, Konsumforschung, G.F., Ed.; 2015; unpublished.

240. Statistisches Bundesamt. Vorausberechneter Bevolkerungsstand; Statistisches Bundesamt: Wiesbaden, Germany, 2017. 
241. Nestlé Deutschland AG. Nestlé Studie 2009: Ernährung in Deutschland 2008-Kurzfassung; Nestlé Deutschland AG: Frankfurt, Germany, 2009.

242. Göbel, R. Praktische Unternehmensführung-Planung, Controlling und Organisatin in Unternehmen der Weinbranche; DLG Verlag: Frankfurt, Germany, 2005.

243. DWI. Neues Marketing für neue Konsumenten; DWI: Mainz, Germany, 2003.

244. Römmelt, W. Schwierige Imagebildung trotz Wachstum. Weinwirtschaft 2012, 20, 31-35.

245. Schön, W. Regionalität ist unsere Stärke. Weinwirtschaft 2018, 9, 26-27.

246. Cusson, A. Trends und Perspektiven des weltweiten Wein-und Spirituosenmarktes bis 2014; Vinexpo-Sopexa: Bordeaux, France, 2011.

247. WeinWir, H.I. Weinimport auf Rekordniveau. Weinwirtschaft 2012, $20,9$.

248. Rückrich, K. Entwicklung der Stillweinimporte. Der Deutsche Weinbau 2012, 22, 9.

249. Pilz, H. Weinimport auf Rekordniveau. Weinwirtschaft 2012, 20, 9.

250. Mathäß, J. Globalisierung im Glas. Rheinpfalz am Sonntag, 30 September 2018; p. 6.

251. Unione Italiana Vini. Import. Wine by numbers, 5. 2017. Available online: http://www.uiv.it/corriere/ english-version/ (accessed on 20 November 2018).

252. Rückrich, K. Weinaußenhandel in der Europäischen Union-Weinimporte im Fokus. Der Deutsche Weinbau 2018, 12, 12.

253. Pilz, H. Von Einäugigen und Blinden. Weinwirtschaft 2012, 20, 46-51.

254. Scheuermann, M. Deutschland als Weindrehscheibe Europas. The Drink Tank 2012, 4, 1-3.

255. Dressler, M. Wein: Globale Chancen für deutsche Anbieter. Der Deutsche Weinbau 2014, 10, 18.

256. Rheinschmidt, K. Abwärtstrend scheint gestoppt. Das Deutsche Weinmagazin 2018, 20, 32-34.

257. Dressler, M. Vertriebsstrategien angepasst an sich änderndes Verbraucherverhalten und schwankende Erntemengen. In Pfälzer Weinbautage 2015; DLR Rheinpfalz: Neustadt, Germany, 2015.

258. Dressler, M. Erfolgsfaktoren im Weinexport und Leistungswahrnehmung deutscher Anbieter. In Deutsches Weinbaujahrbuch 2015; Schultz, H.-R., Stoll, M., Eds.; Ulmer: Stuttgart, Germany, 2015; Volume 66, pp. $146-158$.

259. Hofstede, G. Cultural constraints in management theories. Acad. Manag. Exec. 1993, 7, 81-94. [CrossRef]

260. Kreiser, P.M.; Marino, L.D.; Dickson, P.; Weaver, K.M. Cultural influences on entrepreneurial orientation: The impact of national culture on risk taking and proactiveness in SMEs. Entrep. Theory Pract. 2010, 34, 959-983. [CrossRef]

261. Pagell, M.; Katz, J.P.; Sheu, C. The importance of national culture in operations management research. Int. J. Oper. Prod. Manag. 2005, 25, 371-394. [CrossRef]

262. Wursten, H.; Fadrhonc, T. International Marketing and Culture. ITIM International. 2012. Available online: http://www.academia.edu/22416733/International_marketing_and_Culture (accessed on 20 November 2018).

263. Dressler, M. Managing Export Success-An empirical Picture of German Wineries' Performance. In BIO Web of Conferences; France, 2001; EDP Sciences: Les Ulis, France, 2015; p. 03001.

264. Agri, D. Wine CMO: Submission of Financial Table of the National Support Programme; Commission Regulation EC 555/2008; European Commission: Belgium, Brussels, 2017.

265. Dressler, M. Wahrnehmung der Exportaktivitäten von deutschem Wein-Die "Sicht von außen". In Pfälzer Weinbautage 2016; Rheinpfalz, D., Ed.; DLR Rheinpfalz: Neustadt, Germany, 2016.

266. Dressler, M. Strategic profiling and the value of wine \& tourism initiatives: Exploring strategic grouping of German wineries. Int. J. Wine Bus. Res. 2017, 29, 484-502.

267. Degravel, D. Strategy-As-Practice to Reconcile Small Businesses' Strategies and RBV? J. Manag. Policy Pract. 2012, 13, 46-66.

268. Porter, M.E. How Competitive Forces Shape Strategy. Harvard Businesss Review. Harvard Business School Publishing: Boston, MA, USA, 1979; pp. 137-145.

269. Miles, R.E.S.; Snow, C.C.; Meyer, A.D.; Coleman, H.J. Organizational Strategy, Structure, and Process. Acad. Manag. Rev. 1978, 3, 546-562. [CrossRef]

270. Hoffman, D. Struktur und Entwicklung des Weinmarktes in Deutschland. In Weinbaujahrbuch 2014; Schultz, H.-R., Stoll, M., Eds.; Ulmer: Stuttgart, Germany, 2013; Volume 65, pp. 242-245. 
271. Schnabl, A.; Lappöhn, S.; Pohl, A. Ökonomische Bedeutung der Weinwirtschaft für Österreich; IHS: Vienna, Austria, 2016.

272. Kim, W.C.; Mauborgne, R.A. Blue Ocean Strategy: How to Create Uncontested Market Space and Make the Competition Irrelevant; Harvard Business Review Press: Boston, MA, USA, 2014. 